OPEN ACCESS

Edited by:

Andreas Frey,

Research Center Borstel (LG),

Germany

Reviewed by:

Mogens Kilian,

Aarhus University, Denmark Ashu Sharma,

University at Buffalo, United States

${ }^{*}$ Correspondence:

Bert Devriendt

b.devriendt@ugent.be

Specialty section:

This article was submitted to

Vaccines and Molecular Therapeutics,

a section of the journal

Frontiers in Immunology

Received: 31 August 2021 Accepted: 18 November 2021 Published: 02 December 2021

Citation:

Vaernewyck V, Arzi B, Sanders NN,

Cox E and Devriendt B (2021)

Mucosal Vaccination Against

Periodontal Disease: Current

Status and Opportunities.

Front. Immunol. 12:768397.

doi: 10.3389/fimmu.2021.768397

\section{Mucosal Vaccination Against Periodontal Disease: Current Status and Opportunities}

\author{
Victor Vaernewyck ${ }^{1}$, Boaz Arzi ${ }^{2,3}$, Niek N. Sanders $^{4}$, Eric Cox ${ }^{1}$ and Bert Devriendt ${ }^{1 *}$ \\ 1 Laboratory of Immunology, Department of Translational Physiology, Infectiology and Public Health, Faculty of Veterinary \\ Medicine, Ghent University, Merelbeke, Belgium, ${ }^{2}$ Department of Surgical and Radiological Sciences, School of Veterinary \\ Medicine, University of California, Davis, CA, United States, ${ }^{3}$ Veterinary Institute for Regenerative Cures (VIRC) School of \\ Veterinary Medicine, University of California, Davis, CA, United States, ${ }^{4}$ Laboratory of Gene Therapy, Department of \\ Veterinary and Biosciences, Faculty of Veterinary Medicine, Ghent University, Merelbeke, Belgium
}

Approximately 9 out of 10 adults have some form of periodontal disease, an infection-induced inflammatory disease of the tooth-supporting tissues. The initial form, gingivitis, often remains asymptomatic, but this can evolve into periodontitis, which is typically associated with halitosis, oral pain or discomfort, and tooth loss. Furthermore, periodontitis may contribute to systemic disorders like cardiovascular disease and type 2 diabetes mellitus. Control options remain nonspecific, time-consuming, and costly; largely relying on the removal of dental plaque and calculus by mechanical debridement. However, while dental plaque bacteria trigger periodontal disease, it is the host-specific inflammatory response that acts as main driver of tissue destruction and disease progression. Therefore, periodontal disease control should aim to alter the host's inflammatory response as well as to reduce the bacterial triggers. Vaccines may provide a potent adjunct to mechanical debridement for periodontal disease prevention and treatment. However, the immunopathogenic complexity and polymicrobial aspect of PD appear to complicate the development of periodontal vaccines. Moreover, a successful periodontal vaccine should induce protective immunity in the oral cavity, which proves difficult with traditional vaccination methods. Recent advances in mucosal vaccination may bridge the gap in periodontal vaccine development. In this review, we offer a comprehensive overview of mucosal vaccination strategies to induce protective immunity in the oral cavity for periodontal disease control. Furthermore, we highlight the need for additional research with appropriate and clinically relevant animal models. Finally, we discuss several opportunities in periodontal vaccine development such as multivalency, vaccine formulations, and delivery systems.

Keywords: periodontal disease, gingivitis, periodontitis, mucosal vaccine, periodontal vaccine

\section{INTRODUCTION}

Periodontal disease (PD) is an infection-induced chronic inflammatory disease that affects the tooth-supporting tissues, which are collectively known as the periodontium. In gingivitis, the initial reversible form of $\mathrm{PD}$, inflammation is confined to the gingival epithelium and the connective tissue. If not treated properly, this inflammation can spread to the deeper components of the 
periodontium, including the alveolar bone, leading to periodontitis, the irreversible form of PD (1). Periodontitis can be further classified into four stages (I, II, III, or IV) and three grades (A, B, or C). Staging is based on severity, complexity, extent, and distribution; while grading is based on the rate of progression, anticipated treatment response, and effects on systemic health (2).

Based on the World Health Organization's oral health database, about $90 \%$ of adults have some form of PD (gingivitis or periodontitis) (3). While this estimate is interesting, it does not reflect the clinical impact of PD since many of these cases are asymptomatic. However, the clinical importance of PD is corroborated by the high global prevalence of severe periodontitis, which was estimated at $9.8 \%$ by the Global Burden of Disease (GBD) study (4). PD is also highly prevalent in adult dogs, cats, minipigs, and non-human primates, with anesthetized examination studies reporting prevalences of $86.5 \%$ to $100 \%$ (5-12).

PD typically leads to halitosis, oral pain or discomfort, and periodontal damage which can result in tooth loss (1). Moreover, periodontitis may have a substantial effect on systemic health. Epidemiological, clinical interventional, and experimental studies have provided compelling evidence that periodontitis adversely impacts systemic health in humans. However, clear confirmation that successful treatment of PD can reduce the risk or incidence of PD-associated conditions like atherosclerosis and type 2 diabetes mellitus is lacking $(13,14)$. Veterinary research into the extra-oral effects of periodontitis remains limited, but a growing body of literature suggests similar deleterious effects on systemic health in animals with periodontitis (15-21). In addition to the oral and systemic disease burden, PD also imposes a significant economic burden. The global annual cost (direct and indirect) of human dental diseases was estimated at 544 billion USD in 2015, which is largely attributed to PD and caries (22).

Gingivitis is clinically characterized by gingival redness, swelling, and susceptibility to bleeding. Periodontitis implies loss of gingival attachment to the tooth, degradation of the periodontal ligament and loss of alveolar bone (1). This destructive process is associated with the presence of subgingival polymicrobial communities and a dense immunoinflammatory infiltrate in the periodontium, which can be explained by the polymicrobial synergy and dysbiosis model. This model describes PD as a continuous cyclic process where dysbiotic polymicrobial communities within the subgingival dental plaque induce an immune response that is ineffective, uncontrolled, and destructive in a susceptible host. The resulting inflammatory environment and tissue degradation exacerbate dysbiosis by selectively providing nutrients to inflammophilic bacteria, thereby generating a self-sustained feed-forward loop that perpetuates the disease (23).

The PD-associated polymicrobial communities are nososymbiotic rather than pathogenic, as their collective pathogenic potential depends on both the outcome of interbacterial interactions and host susceptibility. Consequently, the simple dichotomous characterization of microbes as either commensals or pathogens is not adequate to represent the continuum from commensalism to pathogenicity. Instead, several functional categories have been established such as keystone pathogens, accessory pathogens, pathobionts, and homeostatic commensals (24) Keystone pathogens such as Porphyromonas gingivalis have a disproportionately large influence on the quantitative and qualitative microbial composition, thus acting as a keystone of their community's structure. These changes may be induced directly via interspecies interactions and indirectly through subversion of the host immune response (25-29). In addition, there are accessory pathogens (e.g., Streptococcus gordonii), which are generally perceived as symbiotic commensals, but they can promote the virulence of disease-associated organisms by supporting the nutrition and colonization of keystone pathogens (30-33). Next, there are pathobionts (e.g., Treponema denticola, Tannerella forsythia, and Fusobacterium nucleatum), which are inflammophillic commensals that can become pathogenic when host-microbe homeostasis is disrupted under certain conditions, such as inflammation, antibiotic treatment, tissue damage, dietary shifts, and immune deficiencies (34). The fourth major group are homeostatic commensals (e.g., Streptococcus cristatus), which are commensals that stabilize eubiotic communities by directly antagonizing potentially pathogenic microbes or by inducing antimicrobial peptides that preferentially target potential pathogens (35-38).

Current PD control measures heavily rely on the removal of dental plaque and calculus by mechanical debridement. This is usually limited to toothbrushing, interdental cleaning, and nonsurgical periodontal therapy (scaling and root planing), although open flap debridement is occasionally needed (39). While these procedures can prevent the formation of a disease-triggering dysbiotic biofilm, it does not directly affect the latent dysregulated inflammatory cascade in susceptible hosts. Therefore, mechanical debridement requires constant repetition and provides variable prognoses depending on patient compliance and susceptibility (40). Consequently, several adjuncts to mechanical debridement have been proposed to enhance treatment outcomes. This includes pocket reduction surgery (41), regenerative surgery (42), laser therapy (43), and local antimicrobials such as doxycycline or chlorhexidine $(44,45)$. However, current adjunct therapy mostly relies on systemic antibiotics; which typically consists of a broad-spectrum antibiotic alone or in combination with an antibiotic that targets Gram-negative bacteria (39).

The rationale for administration of systemic antimicrobials as an adjunct to non-surgical therapy is to reduce the number of pathogenic bacteria in deep pockets, surface irregularities, furcation areas, and those that have entered the bloodstream. However, the use of antimicrobials is only justified in specific cases of periodontitis, since biofilm-associated infections are difficult to treat with antibiotics, and the use of antimicrobial agents promotes the development antimicrobial resistance (46). Despite these considerations and established clinical guidelines, several studies indicate that systemic antibiotics are still regularly used to control PD without appropriate indications (47-51). 
This injudicious use of antibiotics is alarming, especially considering the ubiquity of PD and the extra-oral distribution of systemic antibiotics, as this contributes to the development of antimicrobial resistance (46). Antimicrobial resistance has evolved as one of the most urgent threats to public health, causing treatment failures, prolonged hospital admissions, and increases in healthcare costs (52). Moreover, several studies indicate high and increasing levels of antimicrobial resistance in subgingival PD-associated bacteria, further exposing the unsustainability of antibiotics-based PD management (53-63). Another drawback of antimicrobials is their non-specific effect on both pathogenic (e.g., keystone and accessory pathogens) and protective oral bacteria (homeostatic commensals) (46).

Since the host inflammatory response acts as main driver of tissue destruction and simultaneously exacerbates dysbiosis, it can be reasoned that adjuncts to mechanical debridement should not rely on nonspecific bacterial clearance by systemic antibiotics, but rather on the alteration of host immune responses. Traditional anti-inflammatory drugs, such as corticosteroids and non-steroidal anti-inflammatory drugs do not offer significant long-term benefits and are precluded for prolonged periodontal treatment due to their adverse effects (6467). However, several promising alternatives have been proposed, including specialized pro-resolving mediators, complement inhibitors, and anti-cytokine therapies. Proresolving mediators are physiological agents such as resolvins, lipoxins, and protectins which accelerate the resolution of inflammation (68). The topical application of such mediators can protect against bone loss in rabbits, rats, and miniature pigs following experimental induction of periodontitis (68-73). Complement inhibitors, on the other hand, aim to suppress the complement system which is overactivated in periodontitis (74-77). Recent studies indicate that topical or systemic administration of $\mathrm{Cp} 40$, an inhibitor of the complement component $\mathrm{C} 3$, inhibits naturally occurring periodontitis in non-human primates $(76,77)$. A third novel approach to immune response modulation are anti-cytokine therapies, which involve the use of neutralizing monoclonal antibodies or receptor antagonists to block the action of proinflammatory cytokines that play a role in periodontitis (78-84). Studies in non-human primates with experimentally induced periodontitis found that local injections with antagonists of interleukin 1 and/ or tumor necrosis factor protected against PD-associated tissue loss $(78-80,83)$.

The three aforementioned strategies could be relevant for future treatment of periodontitis or even its short-term prevention in high-risk individuals; however, these methods seem less useful for long-term prophylaxis (23). In contrast, periodontal vaccines may contribute to long-term prophylaxis, by preventing the subversion of the immune system by keystone PD pathogens, avoiding and reverting dysbiosis, and averting destructive hyperinflammation (23). In addition, periodontal vaccines might discourage the use of antibiotics (46). Efficacious periodontal vaccines will need to elicit protective antibody responses in the oral cavity that are specific for PDinducing bacteria. Local antibody responses in the oral cavity rely on both systemic (IgG) and mucosal immunity (secretory IgA, SIgA). IgG within the oral cavity mainly originates from the blood circulation by passive leakage via the gingival crevicular epithelium, while the SIgA is locally produced in the salivary glands by activated $\mathrm{B}$ cells that migrated from the mucosaassociated lymphoid tissues (MALT) (85). Hence, effective periodontal vaccines must induce both systemic and mucosal immunity in the oral cavity, which has proved difficult with traditional vaccination strategies. This is evident by the current lack of a human periodontal vaccine, while the first vaccines against PD, including the Inava Endocorps vaccine, were already developed in the early twentieth century (86). Similarly, there have been no veterinary periodontal vaccines available since the production of the Porphyromonas-denticanis-gulae-salivosa vaccine against $\mathrm{PD}$ in dogs was halted in 2011 due to its unsatisfactory long-term effects on the disease (87). Fortunately, there has been major progress in the design of mucosal vaccines, offering new methods to induce protective immunity in the oral cavity (88). Another area of improvement is the antigen selection, which is aided by the growing understanding of the polymicrobial compositions and interactions. Based on the current knowledge, successful periodontal vaccines may require multiple specific antigenic targets from different PD-associated bacteria (23). In this review, we provide a comprehensive overview of the current status and future directions of mucosal vaccination against PD.

\section{MUCOSAL VACCINATION AGAINST PERIODONTAL DISEASE}

Mucosal vaccines are more likely to protect against PD than systemic vaccines, since they are generally more successful in simultaneously inducing IgG and salivary SIgA in the oral cavity (88). Indeed, all eleven preclinical studies that evaluated this reported more dual immunity in the oral cavity after mucosal vaccination compared to systemic vaccination (89-99). Furthermore, several studies reported protection against experimental PD-associated bone loss or gingival swelling/ abscessation by mucosal immunization $(91,100-115)$. While these data support the rationale for mucosal PD vaccines, it must be noted that all but two of these studies used rodent PD models $(113,116)$. Rodents have been popular because of their low cost, manageability, prompt availability, and ease of housing. However, rodents have major limitations as translational model of human PD. First, there are marked differences in periodontal anatomy and oral microbiota between rodents and humans. Second, PD does not occur spontaneously in rodents, requiring experimental $\mathrm{PD}$ induction with allochthonous $\mathrm{PD}$ bacteria such as $P$. gingivalis (117). Third, clinical parameters such as bone loss are difficult to measure and interpret in small animals like mice, which is further complicated by the lack of standardization (118). Finally, the lymphoid tissue of the head is different between rodents and humans. Rodents have concentrated lymphoid tissue at the bottom of the nasal ducts, which is either absent or disseminated in humans (119). In the 
human head, most of the lymphoid tissue is organized in the Waldeyer's tonsillar ring, whereas rodents do not have tonsils (120).Non-human primates, dogs and miniature pigs provide more ideal translational models than rodents to study PD therapies. Indeed, non-human primates, dogs, minipigs, and humans all have a high prevalence of PD, and a similar PD etiopathogenesis, periodontal anatomy, oral immune system and oral microbiota $(11,117,121)$. Non-human primate models are considered to bear the closest resemblance to human PD, and they have been used to study PD pathogenesis and treatment modalities including periodontal vaccines (122-124). However, research access to these animals is hindered by limited availability, high costs, ethical considerations, and difficulty in handling $(117,125)$. The dog offers another valuable translational PD model that is easier to obtain and maintain. Therefore it has been one of the most widely used animal models in periodontological studies, including periodontal vaccine development $(113,116,117,126,127)$. The minipig PD model, in contrast, has not yet been used to test periodontal vaccines despite its translational value $(117,125)$. Nevertheless, miniature pigs have been used to assess other PD treatments such as stemcell therapy (128), administration of pro-resolving lipid mediators (71), and photodynamic therapy (129). Therefore, dogs, non-human primates, and minipigs should be considered for future research into mucosal vaccination against $\mathrm{PD}$. In these animal models, PD can be either naturally occurring or experimentally induced (e.g., with ligatures around teeth) (130). These models may facilitate the assessment of oral, intranasal, sublingual, buccal and ocular vaccination against
PD (Figure 1). Furthermore, this may enable a better selection of antigenic targets, vaccine types, adjuvants, and delivery systems for mucosal vaccination against PD.

\section{Oral Vaccination}

Oral vaccines have contributed substantially to the worldwide control of infectious diseases, including the near eradication of poliomyelitis $(131,132)$. The oral route is the most convenient and patient-accepted route of administration (133) and allows dissemination of antigen-specific lymphocytes to other mucosal tissues, such as the gastrointestinal, oral, genital, and respiratory mucosa. On the other hand, oral vaccines must overcome the gastric acid and digestive enzymes, the epithelial barrier, and the tolerogenic immune responses in order to successfully deliver antigens to the gut-associated lymphoid tissue and elicit protective immunity $(134,135)$.

Several studies found significant antigen-specific antibody responses in serum and saliva of mice, rats, and hamsters after peroral vaccination against antigens from human periodontal pathogens (Table 1). Vaccination through oral gavage or intragastric intubation generally resulted in higher levels of salivary SIgA and antibody-producing cells in mucosaassociated tissues compared to subcutaneous and intramuscular immunization $(90,95,96)$. Three studies also assessed the clinical effect of these vaccinations on periodontal health, reporting protection against $P$. gingivalis-induced alveolar bone loss $(103,104)$ or reduced gingival swelling in a mouse gingival abscess model (105). In a first study, rats were orally vaccinated with the oral commensal Streptococcus

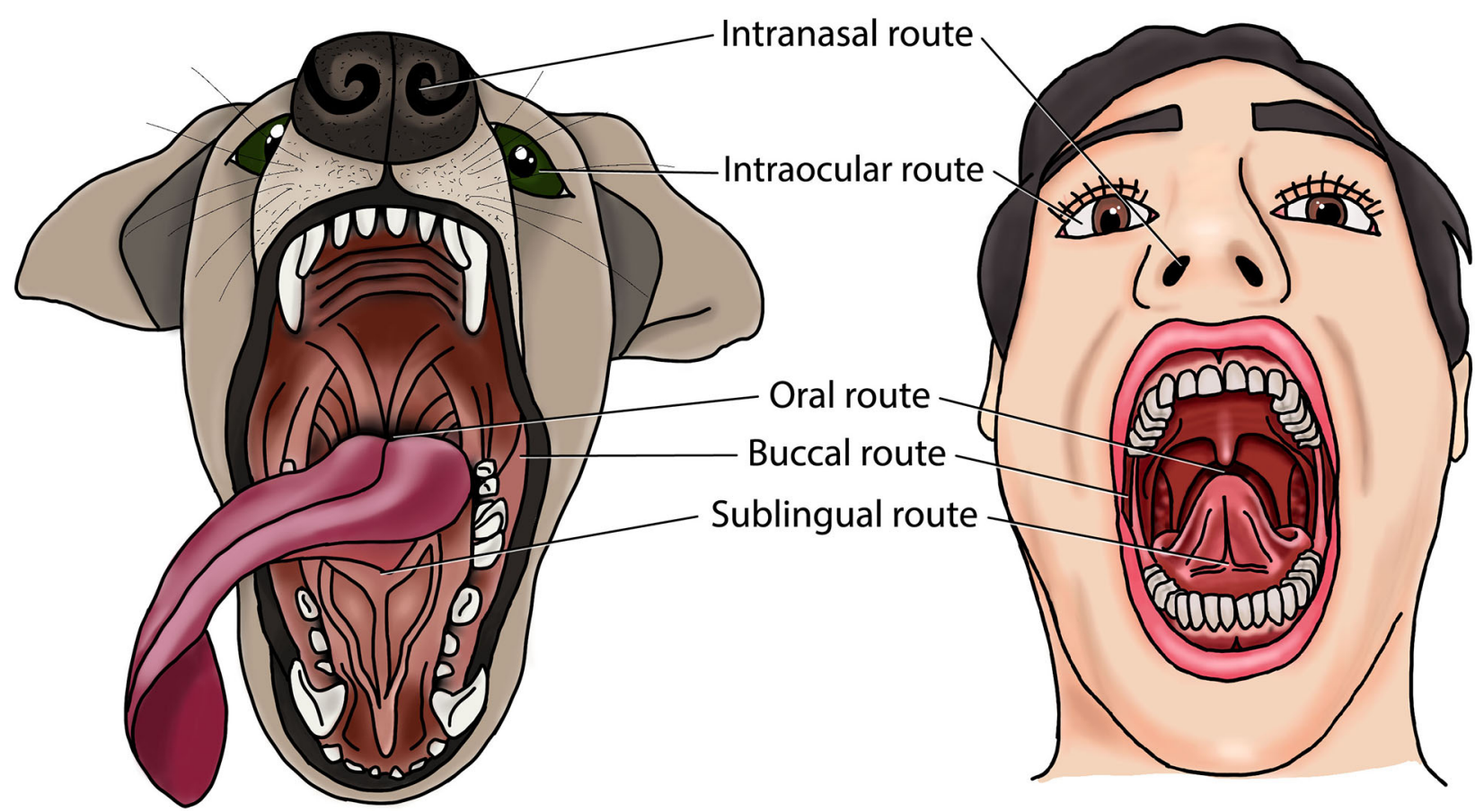

FIGURE 1 | Mucosal routes for periodontal disease vaccination in dogs and humans. 
TABLE 1 | Preclinical development of oral vaccines against periodontal disease, organized per target pathogen.

\begin{tabular}{|c|c|c|c|c|}
\hline Antigen & Delivery/Adjuvant & Model & Results & Ref. \\
\hline \multicolumn{5}{|c|}{ Aggregatibacter actinomycetemcomitans } \\
\hline Fimbrial oligopeptide & $\begin{array}{l}\text { Liposome } \\
\text { IL-4 expression plasmid CT }\end{array}$ & Mouse & $\begin{array}{l}\text { - Serum IgG and salivary IgA responses } \\
\text { - Serum IgG: IM }>P O>\mathbb{I N}^{\mathrm{a}, \mathrm{b}} \\
\text { - Salivary } \lg A: I N>P O>\mathrm{IM}^{\mathrm{a}, \mathrm{b}}\end{array}$ & (90) \\
\hline \multicolumn{5}{|l|}{ Fusobacterium nucleatum } \\
\hline FomA protein & Live carrier: Lactobacillus acidophilus & Mouse & $\begin{array}{l}\text { - Serum IgG and salivary lgA responses } \\
\text { - Abs reduce } P \text {. gingivalis - F. nucleatum coaggregation in vitro } \\
\text { - Reduced } P \text {. gingivalis/F. nucleatum-induced gingival swelling }\end{array}$ & $(105)$ \\
\hline \multicolumn{5}{|l|}{ Porphyromonas gingivalis } \\
\hline $\begin{array}{l}\text { Whole cells } \\
\text { (formalin-inactivated) }\end{array}$ & & Hamster & $\begin{array}{l}\text { - Serum and salivary } A b \text { response } \\
\text { - Serum } A b: S C>P O{ }^{a, b} \\
\text { - No significant reduction in } P \text {. gingivalis colonization }\end{array}$ & (96) \\
\hline Fimbriae & CT & Mouse & $\begin{array}{l}\text { - Serum IgM, IgG, and IgA responses } \\
\text { - IgG and IgA responses in saliva and fecal extract } \\
\text { - Salivary IgA and IgG: IN > PO } \\
\text { - Higher antibody levels with CT }\end{array}$ & $(136,137)$ \\
\hline Fimbriae & $\begin{array}{l}\text { Liposome } \\
\text { GM-53 or MDP-Lys(L18) }\end{array}$ & Mouse & $\begin{array}{l}\text { - Serum IgM, IgG, and IgA responses } \\
\text { - Salivary IgA response } \\
\text { - Serum IgG: SC > PO a,b } \\
\text { - Salivary IgA: PO } \geq \text { SC } \\
\text { - Adjuvant: GM-53 > MDP-Lys(L18) }\end{array}$ & $(92,94,95)$ \\
\hline FimA (residues 55-145 or 226-337) & Live carrier: Streptococcus gordonii & Rat & $\begin{array}{l}\text { - Serum IgG and IgA responses } \\
\text { - Salivary IgA response } \\
\text { - Reduced } P \text {. gingivalis-induced alveolar bone loss }\end{array}$ & $(103)$ \\
\hline FimA (residues 1-200 or 201-337) & CTB (fusion) & Mouse & $\begin{array}{l}\text { - Serum IgG and fecal lgA responses } \\
\text { - No serum lgG and lower level of fecal lgA in absence of CTB }\end{array}$ & $(138)$ \\
\hline Hemagglutinin A & Live carrier: Salmonella Typhimurium & Mouse & - Antigen-specific serum antibody response & $(139)$ \\
\hline Hemagglutinin B & Live carrier: Salmonella Typhimurium & Mouse & $\begin{array}{l}\text { - Serum IgG and IgA responses } \\
\text { - Salivary, biliary, vaginal, and fecal lgA responses } \\
\text { - Serum IgG: surface-expressed } \mathrm{Ag}>\text { cytoplasm expressed Ag }\end{array}$ & $(140-142)$ \\
\hline 40k-OMP & CT & Mouse & $\begin{array}{l}\text { - Serum IgM, IgG, and IgA responses } \\
\text { - Salivary, nasal, and fecal lgA responses } \\
\text { - Serum IgG: IN >SL > PO a } \\
\text { - Salivary } \lg A: I N \approx S L>P O O^{a}\end{array}$ & $(143)$ \\
\hline 40k-OMP & CT or CpG ODN & Mouse & $\begin{array}{l}\text { - Serum IgG and IgA responses } \\
\text { - Salivary IgA response } \\
\text { - Adjuvant: CpG ODN > CT > None } \\
\text { - Reduced } P \text {. gingivalis-induced alveolar bone loss }\end{array}$ & (104) \\
\hline
\end{tabular}

${ }^{a}$ different dosing was used per administration route.

${ }^{b}$ different adjuvants were used for different administration routes.

40k-OMP, 40-kDa outer membrane protein; Ab(s), antibody(-ies); Ag, antigen; CpG ODN, CpG oligodeoxynucleotides; CT, cholera toxin; CTB, cholera toxin subunit B; FimA, fimbrillin; FomA, Fusobacterial outer membrane protein A; GM-53 \& MDP-Lys(L18), acyl derivatives of muramylpeptides; IgA/G/M, immunoglobulin A/G/M; IL-4, interleukin 4; IM, intramuscular; IN, intranasal; PO, per os;SC, subcutaneous; SL, sublingual.

gordonii that was engineered to express domains of $P$. gingivalis fimbrillin (FimA). This induced antigen-specific serum IgG, serum IgA and salivary SIgA, which protected against alveolar bone loss following $P$. gingivalis challenge (103). In another study, mice were orally immunized with the $40-\mathrm{kDa}$ outer membrane protein of $P$. gingivalis (40k-OMP), adjuvanted with $\mathrm{CpG}$ oligodeoxynucleotides $(\mathrm{CpG})$ or cholera toxin (CT). In contrast to the non-adjuvanted group, vaccination with 40k-OMP plus $\mathrm{CpG}$ or CT resulted in strong serum IgG and $\operatorname{IgA}$, while only 40k-OMP plus $\mathrm{CpG}$ induced strong salivary SIgA responses. More importantly, while both groups had less alveolar bone loss following $P$. gingivalis challenge compared to the control and non-adjuvanted group, 40k-OMP plus CpG ODN provided significantly more protection than 40k-OMP plus CT (104).. The most recent of these three studies assessed the clinical effect of vaccination in a mouse gingival abscess model, where abscessation was induced by injecting a bacterial suspension in the gingiva. Vaccination was performed by oral administration of recombinant Lactobacillus acidophilus expressing the major outer membrane porin protein of the pathobiont F. nucleatum (FomA). Immunization with this live carrier induced antigen-specific serum IgG and salivary SIgA. Moreover, when the resulting serum was incubated with $F$. nucleatum in vitro, the coaggregation with $P$. gingivalis was significantly reduced. When abscesses were induced in these mice using $F$. nucleatum by itself or with $P$. gingivalis, the vaccinated mice had significantly less abscessation (105).

Overall, the oral vaccination studies have been encouraging, but research into mucosal periodontal vaccines has recently shifted towards nasal and sublingual immunization, which generally induce higher levels of salivary $\operatorname{SIgA}(90,136,143)$. 


\section{Intranasal Vaccination}

The intranasal route is the second major mucosal route, with the nasal influenza vaccine as pioneering application in humans (131). Compared to the oral vaccination route, intranasal administration has the advantages of avoiding the gastric degradation of oral vaccines. On the other hand there exists a risk of retrograde neuronal migration of vaccine components in the olfactory or facial nerve, which can cause neural issues like transient facial nerve paralysis $(144,145)$. Fortunately, this risk may be mitigated by avoiding the use of certain adjuvants and antigens that are prone to neuronal accumulation, including cholera toxin and Escherichia coli heat labile toxin. Indeed, Du et al. reported less neuronal accumulation following intranasal immunization against PD when using antigen-fused $E$. coli maltose-binding protein as an alternative adjuvant to cholera toxin, while providing similar protection against alveolar bone loss (111).

The reviewed intranasal $\mathrm{PD}$ vaccination studies reported varying levels of antigen-specific antibody responses in serum and saliva of mice, rats, and dogs (Table 2). Eight of these studies also demonstrated various protective effects of the induced antibodies in vitro, including inhibited bacterial co-aggregation, decreased biofilm formation, reduced bacterial invasion of epithelial cells, and decreased pathogen viability (93, 99, 108$110,114,147,148)$. Moreover, several in vivo experiments indicated that intranasal vaccination against certain antigens of P. gingivalis, F. nucleatum, or Eikenella corrodens can protect against experimentally induced alveolar bone loss or gingival swelling/abscessation in mice, rats, or dogs (91, 100-102, 108, 110-115). Nonetheless, the significant differences between nasal lymphoid tissue in rodents and humans must be taken into account when extrapolating these results (154). Furthermore, intranasal vaccination in mice is often associated with inhalation and ingestion of vaccine antigens, making discrimination between intranasal, oral, and intrapulmonary vaccination difficult (155). These limitations further highlight the unexploited value of appropriate and clinically relevant animal models.

The antigenic targets of the intranasal vaccines were very similar to those included in the oral vaccines, with $P$. gingivalis gingipains as the most used addition. Gingipains are cysteine proteases that are surface-bound and secreted, comprising RgpA and $\operatorname{RgpB}$ with arginine-specific activity, and Kgp with lysinespecific activity (156). They function as proteinases and transpeptidases, aiding $P$. gingivalis' adherence, growth, development, evasion of host defenses and processing of surface-associated proteins (157-160). Moreover, Kgp has the ability to cleave IgG and IgA at specific sites within the immunoglobulin $(158,161)$. Our review includes five studies that assessed the effects of intranasal vaccination of murine PD models against (a domain of) gingipains (91, 99, 114, 115, 153). While different protein and DNA designs were used, each construct was able to induce significant antigen-specific serum IgG and salivary SIgA responses. Moreover, the studies that assessed the clinical effects of vaccination found significantly less experimentally induced alveolar bone loss in immunized mice (91, 114, 115). Interestingly, the most recent of these studies compared vaccination against a gingipain domain (Hgp44 domain of RgpA), a membrane protein of $F$. nucleatum (truncated form of FomA), or both. All three vaccines were able to reduce alveolar bone destruction following bacterial challenge with $F$. nucleatum and $P$. gingivalis. However, based on bone volume density, the divalent vaccine provided significantly more protection than the monovalent vaccines (114). In conclusion, the aforementioned studies support the potential of gingipains as a vaccine target and the probable benefit of multivalent periodontal vaccines, although additional research is required in appropriate PD models.

The collected data suggests that intranasal vaccination against PD generally elicits higher levels of salivary IgA compared to oral and parenteral immunization in mice and dogs (89-91, 93, 9799, 113, 136, 143). However, to achieve these responses, intranasally administered vaccines must overcome profuse mucosal secretions, mucociliary clearance, and the relative inefficient uptake of antigens by antigen-presenting cells in the nasal cavity (162). Therefore, the efficacy of intranasal vaccination is especially dependent on adjuvants, which is highlighted by several studies where the omission of adjuvant resulted in the lack of significant antibody responses $(97,101$, $111,146,148)$. Furthermore, the intranasal route seems to be the only mucosal vaccination route that tested DNA-based vaccines against PD. All four of these vaccination studies targeted antigens of the keystone pathogen $P$. gingivalis and reported strong antigen-specific salivary SIgA responses after intranasal administration of the DNA-based vaccine $(89,91,102,112)$. Moreover, three of these studies assessed the effect of the vaccination on $P$. gingivalis-induced alveolar bone loss, which was reduced in all three studies $(91,102,112)$. These findings stress the unexplored potential of nucleic acid-based vaccines against $\mathrm{PD}$, demanding additional research into DNA and RNAbased vaccines for PD control.

\section{Sublingual, Buccal, and Intraocular Vaccination}

To date, there are no vaccines available that use the sublingual, buccal, or intraocular administration route, except the recently commercialized sublingual vaccine Uromune ${ }^{\circledR}$ for recurrent urinary tract infections (163). Nevertheless, these mucosal vaccination routes have several advantages including the avoidance of the gastric degradation that challenges oral vaccines (131). Furthermore, these administration routes do not impose the risk of retrograde neuronal migration of vaccine components which can occur after intranasal vaccination $(144,145)$. On the other hand, the development of such vaccines has been hindered by certain physicochemical barriers. Sublingual and buccal vaccines are challenged by the salivary flow and constant movement of tongue and masticatory muscles, while intraocular vaccines are exposed to lacrimal fluid and palpebral movement. However, the rapid progress in vaccine delivery technology offers a promising future for these underused vaccination routes $(164,165)$.

Studies assessing sublingual, buccal, and ocular vaccination against PD remain very limited. A few studies assessed sublingual 
TABLE 2 | Preclinical development of intranasal vaccines against periodontal disease, organized per target pathogen.

\begin{tabular}{|c|c|c|c|c|}
\hline Antigen & Delivery/Adjuvant & Model & Results & Ref. \\
\hline \multicolumn{5}{|c|}{ Aggregatibacter actinomycetemcomitans } \\
\hline Fimbrial oligopeptide & $\begin{array}{l}\text { Liposome } \\
\text { IL-4 expression plasmid } \\
\text { CT }\end{array}$ & Mouse & $\begin{array}{l}\text { - Serum IgG and salivary IgA responses } \\
\text { - Serum IgG: IM }>P O>\mathbb{I N}^{\mathrm{a}, \mathrm{b}} \\
\text { - Salivary } \lg A: \mathbb{I N}>\mathrm{PO}>\mathrm{IM}^{\mathrm{a}, \mathrm{b}}\end{array}$ & $(90)$ \\
\hline $\begin{array}{l}\text { Serotype b-specific } \\
\text { polysaccharide }\end{array}$ & $\begin{array}{l}\text { BSA (fusion) } \\
\text { CTB }\end{array}$ & Mouse & $\begin{array}{l}\text { - Serum IgM, IgG, and IgA responses } \\
\text { - No significant salivary Abs response } \\
\text { - Serum IgA: IN }>S C^{a, b} \\
\text { - Serum IgG: SC > IN }{ }^{a, b} \\
\text { - BSA (fusion) and CTB required for significant Ab induction }\end{array}$ & $(97)$ \\
\hline \multicolumn{5}{|c|}{ Fusobacterium nucleatum } \\
\hline $\begin{array}{l}\text { Whole cells } \\
\text { (UV-inactivated) }\end{array}$ & & Mouse & $\begin{array}{l}\text { - Serum IgG response } \\
\text { - Abs reduce biofilm formation and VSC production in vitro } \\
\text { - Reduced } P \text {. gingivalis/F. nucleatum-induced gingival swelling }\end{array}$ & $(109)$ \\
\hline FomA & CT & Mouse & $\begin{array}{l}\text { - Serum IgG and IgA responses } \\
\text { - Salivary and nasal IgA responses } \\
\text { - CT required to induce significant Ab levels }\end{array}$ & $(146)$ \\
\hline FomA & $\begin{array}{l}\text { Inactivated carrier: } \\
\text { Escherichia coli }\end{array}$ & Mouse & $\begin{array}{l}\text { - Serum IgG response } \\
\text { - Abs reduce F. nucleatum co-aggregation with } P \text {. gingivalis, biofilm formation and VSC } \\
\text { production } \\
\text { - Reduced } P \text {. gingivalis/F. nucleatum-induced gingival swelling }\end{array}$ & $(110)$ \\
\hline \multicolumn{5}{|c|}{ Fusobacterium nucleatum and Porphyromonas gingivalis } \\
\hline $\begin{array}{l}\text { Truncated FomA } \\
\text { RgpA (Hgp44 domain) }\end{array}$ & FlaB (fusion) & Mouse & $\begin{array}{l}\text { - Serum IgG and salivary IgA responses } \\
\text { - FlaB (fusion) is a potent mucosal adjuvant } \\
\text { - Divalent vaccine Abs reduced } F \text {. nucleatum-mediated biofilm formation, co-aggregation of } P \text {. } \\
\text { gingivalis and Treponema denticola, and } P \text {. gingivalis-host cell interactions in vitro } \\
\text { - Reduced } P \text {. gingivalis/F. nucleatum-induced alveolar bone loss: Divalent vaccine }>\text { monovalent } \\
\text { vaccines }\end{array}$ & $(114)$ \\
\hline \multicolumn{5}{|c|}{ Porphyromonas gingivalis } \\
\hline Fimbriae & CTB & Mouse & $\begin{array}{l}\text { - Serum IgG and IgA responses } \\
\text { - Salivary, nasal, and pulmonary lgA responses } \\
\text { - CTB enhanced Ab titers, especially salivary lgA } \\
\text { - Reduced } P \text {. gingivalis-mediated alveolar bone loss }\end{array}$ & $(100)$ \\
\hline Fimbriae & CT & Mouse & $\begin{array}{l}\text { - Serum } \lg M \text {, IgG, and IgA responses } \\
\text { - IgG and IgA responses in saliva and nasal wash } \\
\text { - Salivary IgA and IgG: IN > PO }\end{array}$ & $(136)$ \\
\hline FimA (DNA) & $\begin{array}{l}\text { DNA plasmid: } \\
\text { FimA } \\
\text { IL-15 }\end{array}$ & Mouse & $\begin{array}{l}\text { - Serum IgG and salivary IgA responses } \\
\text { - Serum IgG: IN } \approx I M \\
\text { - Salivary IgA: IN > IM } \\
\text { - IL-15 enhanced salivary IgA response }\end{array}$ & (89) \\
\hline FimA (DNA) & $\begin{array}{l}\text { DNA plasmid: } \\
\text { FimA } \\
\text { CTLA4 }\end{array}$ & Mouse & $\begin{array}{l}\text { - Serum IgG and salivary IgA responses } \\
\text { - Reduced P. gingivalis-induced alveolar bone loss } \\
\text { - CLA4 enhanced Ab responses and alveolar bone loss reduction }\end{array}$ & $(112)$ \\
\hline FimA (DNA) & DNA plasmid: & Rat & - Salivary IgA responses & \\
\hline Hemagluttinin 2 (DNA) & $\begin{array}{l}\text { FimA } \\
\text { HA2 } \\
\pm \text { IL } 15 \\
\pm \text { CpG ODN }\end{array}$ & & $\begin{array}{l}\text { - Salivary IgA: plasmid excl. IL15 } \approx \text { plasmid incl. IL15 < plasmid excl. IL } 15+\text { CpG ODN }(30 \mu g) \\
\text { - Significantly lower levels of COX-2 and RANKL in rats vaccinated with the plasmid excl. IL15 + } \\
\text { CpG ODN }(30 \mu \mathrm{g})\end{array}$ & $(102)$ \\
\hline FimA protein & $\begin{array}{l}\text { DNA plasmid: } \\
\text { Flt3L } \\
\text { CpG ODN }\end{array}$ & Mouse & $\begin{array}{l}\text { - Serum IgG and IgA responses } \\
\text { - Salivary IgA response } \\
\text { - The DNA plasmid strengthened the Ab responses } \\
\text { - IgA inhibits } P \text {. gingivalis binding to salivary statherin }\end{array}$ & $(147)$ \\
\hline 40k-OMP & CT & Mouse & $\begin{array}{l}\text { - Serum IgM, IgG, and IgA responses } \\
\text { - Salivary, nasal, and fecal IgA responses } \\
\text { - Serum IgG: IN }>S L>P O \text { a } \\
\text { - Salivary IgA: IN } \approx S L>P O \text { a } \\
\text { - CT required for IgA responses and strengthened IgG responses } \\
\text { - IgG reduces co-aggregation of } P \text {. gingivalis and Streptococcus gordonii }\end{array}$ & $\begin{array}{l}(143 \\
148 \\
149)\end{array}$ \\
\hline 40k-OMP & mCTA/LTB or CT & Mouse & $\begin{array}{l}\text { - Serum IgG and IgA responses } \\
\text { - Salivary IgA response } \\
\text { - IgG inhibited coaggregation and hemagglutinin activities of } P \text {. gingivalis in vitro } \\
\text { - mCTA/LTB and CT enhanced Ab production } \\
\text { - Less IgE when using mCTAVLTB adjuvant compared to CT } \\
\text { - Reduced } P \text {. gingivalis-mediated alveolar bone loss }\end{array}$ & $(108)$ \\
\hline
\end{tabular}


TABLE 2 | Continued

\begin{tabular}{|c|c|c|c|c|}
\hline Antigen & Delivery/Adjuvant & Model & Results & Ref. \\
\hline $\begin{array}{l}\text { Outer membrane } \\
\text { vesicles }\end{array}$ & poly (l:C) & Mouse & $\begin{array}{l}\text { - Serum IgG and IgA responses } \\
\text { - Salivary and nasal IgA responses } \\
\text { - Salivary IgA: IN > SC a,b } \\
\text { - Poly (I:C) enhanced Ab responses } \\
\text { - Serum Abs decreased } P \text {. gingivalis viability in vitro } \\
\text { - Decreased numbers of } P \text {. gingivalis in the oral cavity }\end{array}$ & $\begin{array}{l}(93 \\
150 \\
151)\end{array}$ \\
\hline $\begin{array}{l}\text { Hemagglutinin A (25- } \\
\text { kDa antigenic region) }\end{array}$ & MBP (fusion) or CT & Mouse & $\begin{array}{l}\text { - Serum IgG and IgA responses } \\
\text { - Salivary IgA response } \\
\text { - MBP (fusion) or CT required for Ab responses } \\
\text { - Reduced } P \text {. gingivalis-mediated alveolar bone loss } \\
\text { - Accumulation in neuronal tissues: MBP (fusion) < CT }\end{array}$ & $(111)$ \\
\hline Hemagglutinin B & $\begin{array}{l}\text { MPL, GPI-0100, alum, } \\
\text { CTB, LT, or LT (E112K) }\end{array}$ & Mouse & $\begin{array}{l}\text { - Serum IgG and salivary } \lg A \text { response } \\
\text { - Vaginal IgG and } \lg A \text { response } \\
\text { - Salivary IgA: IN > SC }{ }^{a, b} \\
\text { - All adjuvants enhanced Ab responses, especially the LTs } \\
\text { - Serum IgG: surface-expressed } \mathrm{Ag}>\text { cytoplasm expressed Ag }\end{array}$ & $\begin{array}{r}(98 \\
152)\end{array}$ \\
\hline $\operatorname{RgpA}(\mathrm{DNA})$ & HVJ envelope vector & Mouse & $\begin{array}{l}\text { - Serum IgG and salivary IgA responses } \\
\text { - Salivary IgA: IN > ID (gene gun) } \\
\text { - Reduced } P \text {. gingivalis-mediated alveolar bone loss }\end{array}$ & (91) \\
\hline RgpA (hgp44 domain) & FlaB or FlaB (fusion) & Mouse & $\begin{array}{l}\text { - Serum IgG and salivary lgA responses } \\
\text { - Adjuvant: FlaB (fusion) }>\text { FlaB }>\text { none } \\
\text { - Serum IgG: IN > SL }{ }^{a} \\
\text { - Reduced P. gingivalis-mediated alveolar bone loss }\end{array}$ & $(115)$ \\
\hline Kgp (HArep domain) & $\begin{array}{l}\text { CTB, CTB (fusion), MPL, } \\
\text { or LT }\end{array}$ & Mouse & $\begin{array}{l}\text { - Serum IgG response } \\
\text { - Salivary and vaginal IgA responses } \\
\text { - Serum IgG: } S C \geq \mathbb{I N}^{\text {a }} \\
\text { - All adjuvants enhanced Ab responses, especially the CTBs } \\
\text { - Abs reduce } P \text {. gingivalis invasion of epithelial cells in vitro }\end{array}$ & $\begin{array}{r}(99 \\
153)\end{array}$ \\
\hline GroEL & CpG ODN & Mouse & $\begin{array}{l}\text { - Serum IgM, IgG, and IgA responses } \\
\text { - Salivary and nasal IgA responses } \\
\text { - CpG ODN required for Ab responses } \\
\text { - Reduced } P \text {. gingivalis-mediated alveolar bone loss }\end{array}$ & (101) \\
\hline \multicolumn{5}{|l|}{ Eikenella corrodens } \\
\hline Lysine decarboxylase & carbigen $^{\mathrm{TM}}$ & Dog & $\begin{array}{l}\text { - IN immunization induced a serum IgA response that remained throughout the study period } \\
\text { - SC immunization induced a temporary serum IgG response } \\
\text { - No significant effect on dental plaque formation } \\
\text { - Reduced gingivitis in both IN and SC vaccinated groups }\end{array}$ & (113) \\
\hline
\end{tabular}

adifferent dosing was used per administration route.

${ }^{b}$ different adjuvants were used for different administration routes.

40k-OMP, 40-kDa outer membrane protein; Ab(s), antibody(-ies); Ag, antigen; alum, aluminum potassium sulfate; BSA, bovine serum albumin; COX-2, cyclooxygenase-2; CpG ODN, CpG oligodeoxynucleotides; CT, cholera toxin; CTB, cholera toxin subunit B; CTLA4, cytotoxic Tlymphocyte-associated antigen 4; FimA, fimbrillin; FlaB, a major flagellin of Vibrio vulnificus; Flt3L, FMS-like tyrosine kinase 3 ligand; FomA, Fusobacterial outer membrane protein A; GPI-0100, a fractionated quillaja saponin derivative; GroEL, a homolog of heat shock protein 60; HVJ, hemagglutinating virus of Japan; ID, intradermal; IgAVE/G/M, immunoglobulin AVE/G/M; IL-4/15, interleukin 4/15; IM, intramuscular; IN, intranasal; LT, heat-labile enterotoxin of Escherichia coli; MBP, maltose-binding protein of E. coli; MCTA/LTB, chimere combining subunit $A$ of mutant cholera toxin E112K with subunit B of heat-labile enterotoxin from E. coli; MPL, monophosphoryl lipid A; PO, per os; poly (l:C), polyriboinosinic polyribocytidylic acid; RANKL, Receptor activator of nuclear factor kappa-B ligand; RgpA, Arginine-specific gingipain; SC, subcutaneous; SL, sublingual; VSC, volatile sulfur compounds.

vaccination against $\mathrm{PD}$ in murine models (Table 3 ), and demonstrated similar salivary SIgA levels but significantly lower serum IgG levels compared to intranasal vaccination $(115,143)$. Moreover, Puth et al. found a significant reduction in $P$. gingivalis-induced alveolar bone loss in mice after sublingual vaccination against this keystone $\mathrm{PD}$ pathogen, although an even higher level of protection was found after intranasal administration of the same vaccine (115). Thus far, no studies have assessed the buccal administration route for PD vaccination, but one study has used the intraocular route. Shimizu and colleagues assessed the antibody response in dogs after intraocular immunization with $P$. gingivalis cell lysate incorporated in $\mathrm{pH}$-sensitive fusogenic polymer-modified liposomes. This intraocular vaccination induced high titers of antigen-specific serum IgG, serum IgA, and salivary SIgA. Moreover, these salivary antibodies inhibited $P$. gingivalis adherence to HeLa cells, reduced coaggregation with the synergistic oral pathogen Actinomyces naeslundii, and protected human oral epithelial cells against $P$. gingivalisinduced cytotoxicity (116). While these data are encouraging for the development of mucosal vaccines against PD in dogs and humans, it should be noted that data on clinical effects of mucosal vaccination against $\mathrm{PD}$ in non-rodent models remains limited (113). Therefore, future research using appropriate PD animal models should assess clinical parameters such as alveolar bone loss. 
TABLE 3 | Preclinical development of sublingual vaccines against periodontal disease organized per target pathogen.

\begin{tabular}{|c|c|c|c|c|}
\hline Antigen & Delivery/Adjuvant & Model & Results & Ref. \\
\hline \multicolumn{5}{|l|}{ Porphyromonas gingivalis } \\
\hline 40k-OMP & CT & Mouse & $\begin{array}{l}\text { - Serum IgM, IgG, and IgA responses } \\
\text { - Salivary, nasal, and fecal IgA responses } \\
\text { - Serum IgG: IN }>S L>P O^{a} \\
\text { - Salivary IgA: IN } \approx S L>P O^{a} \\
\text { - CT required for IgA responses and strengthened IgG response } \\
\text { - IgG reduces co-aggregation of } P \text {. gingivalis and Streptococcus gordonii }\end{array}$ & $(143)$ \\
\hline 40k-OMP & Flt3L expression plasmid or CT & Mouse & $\begin{array}{l}\text { - Serum IgG and IgA responses } \\
\text { - Salivary IgA response } \\
\text { - Flt3L expression plasmid or CT required for IgA responses } \\
\text { - Serum Ab responses: CT > Flt3L expression plasmid } \\
\text { - Reduced } P \text {. gingivalis-mediated alveolar bone loss }\end{array}$ & $(106)$ \\
\hline Hemagglutinin A (25-kDa antigenic region) & MBP (fusion) & Mouse & $\begin{array}{l}\text { - Serum IgG and IgA responses } \\
\text { - Salivary IgA response } \\
\text { - MBP required for IgA responses } \\
\text { - Serum Abs decreased } P \text {. gingivalis viability in vitro } \\
\text { - Reduced } P \text {. gingivalis-mediated alveolar bone loss }\end{array}$ & $(107)$ \\
\hline RgpA (hgp44 domain) & FlaB or FlaB (fusion) & Mouse & $\begin{array}{l}\text { - Serum IgG and salivary IgA responses } \\
\text { - Adjuvant: FlaB (fusion) }>\text { FlaB }>\text { none } \\
\text { - Serum IgG: IN > SL }{ }^{a} \\
\text { - Reduced P. gingivalis-mediated alveolar bone loss }\end{array}$ & $(115)$ \\
\hline GroEL & CpG ODN or CT & Mouse & $\begin{array}{l}\text { - Serum IgG and salivary IgA responses } \\
\text { - CpG ODN or CT required for Ab responses }\end{array}$ & $(166)$ \\
\hline
\end{tabular}

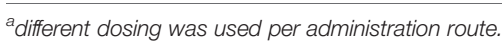

40k-OMP, 40-kDa outer membrane protein; Ab(s), antibody(-ies); CpG ODN, CpG oligodeoxynucleotides; CT, cholera toxin; FlaB, a major flagellin of Vibrio vulnificus; Flt3L, FMS-like tyrosine kinase 3 ligand; GroEL, a homolog of heat shock protein 60; IgA/G/M, immunoglobulin A/G/M; IN, intranasal; MBP, maltose-binding protein of E. coli; PO, per os; RgpA, Argininespecific gingipain; SL, sublingual.

\section{OPPORTUNITIES}

\section{Mucosal Vaccination Routes}

Mucosal vaccination is steadily gaining interest due to their demonstrable advantages over systemic vaccination, and their increasingly efficient vaccine formulations and delivery systems (167). These advancements may accelerate the development of periodontal vaccines, which could benefit from a mucosal vaccination approach that induces both mucosal and systemic immunity in the oral cavity (88). Over the past decade, the sublingual and buccal vaccination have gained significant interest, as demonstrated by the numerous pre-clinical and clinical trials $(163,164,168)$. This may inspire intensified research into sublingual and buccal vaccination against $\mathrm{PD}$, which has so far received little attention compared to the intranasal and oral routes.

\section{Vaccine Targets}

The earliest periodontal vaccines included inactivated bacteria that were easy to culture after isolation from oral sites with PD (86). Later, with the emergence of culture-independent methods, the reliance on culturability decreased and several PD-associated bacterial complexes were identified. The "red" complex comprised three species that were strongly associated with each other and with PD sites: Porphyromonas gingivalis, Tannerella forsythia, and Treponema denticola (169). However, while the identification was no longer culture-based, subsequent vaccine studies remained mostly limited to the easiest of these three bacteria to grow and genetically manipulate, namely $P$. gingivalis
(170). Moreover, this selection approach continued to be based on the bacteria's presence at PD sites rather than their role in the development of the disease. Nevertheless, follow-up research supported the importance of $P$. gingivalis, which is currently considered as the primary keystone pathogen in human PD (24). Similarly, a catalase-positive form of $P$. gingivalis, called $P$. gulae, is associated with PD in dogs (171).

Most periodontal vaccine studies have targeted antigens of $P$. gingivalis, while a smaller portion have focused on Fusobacterium nucleatum and Aggregatibacter actinomycetemcomitans. F. nucleatum is considered as a pathobiont although some strains could act as homeostatic commensals, while A. actinomycetemcomitans is viewed as a pathobiont that can act as a keystone pathogen in localized aggressive periodontitis (172-175). Furthermore, several other potential PD-inducing bacteria including Filifactor alocis and Desulfobulbus oralis have only recently been identified by cultureindependent methods (24). Overall, additional research is needed to gain insights into the roles of the different $\mathrm{PD}$-associated bacterial species in the pathogenesis. This will facilitate the selection of bacterial targets, which may become more specific as we gain better insights into the virulence factors of $\mathrm{PD}$-associated pathogens. Moreover, there are increasingly efficient antigenprediction tools that can further contribute to vaccine specificity which reduces cross-reactions, and thereby improves safety and efficacy of periodontal vaccines (176). Furthermore, these antigenic targets could be combined in multivalent vaccines, potentially further enhancing the efficacy of periodontal subunit vaccines which have so far been mostly monovalent (23). 
Vaccine Formulation and Delivery Systems

Four DNA-based vaccination studies suggest that nucleic acidbased vaccines may induce protective immunity against $\mathrm{PD}$ in the oral cavity $(89,91,102,112)$. Nucleic acid vaccines allow rapid, scalable, and generic production of vaccines that are efficacious at low dosage. Initial concerns about integration of exogenous DNA into the genome have subsided following clinical trials demonstrating the safety of DNA vaccines. The integration of RNA-based vaccines into the host genome is even less likely, since this would only be possible in the presence of retroviral enzymes such as reverse transcriptase and integrase (177). While both types appear safe, DNA has historically received more attention due to its higher inherent stability and lower innate immunogenicity, as well as the excellent results in rodents. However, translation to larger mammalians has been less successful. Messenger RNA (mRNA) vaccines are steadily gaining interest due to three major developments. Firstly, the use of modified nucleosides has greatly improved mRNA stability, while decreasing its innate immunogenicity (177). Secondly, there has been substantial progress in the mRNA vaccine delivery systems such as lipid nanoparticles, which has further improved stability and effectiveness of mRNA vaccines (178). The third major development occurred during the COVID-19 pandemic, when the first mRNA vaccines proved safe and highly effective against the SARS-CoV-2 virus (179). These breakthroughs may encourage the development of new nucleic acid vaccines against $\mathrm{PD}$, which should no longer be limited to DNA-based vaccines.

Concurrent progress in mucosal adjuvant technologies offers additional opportunities for periodontal vaccine development. Most of the reviewed studies used bacterial adjuvants, while only a few evaluated innovative nucleic acid adjuvants $(93,101,102,104,147,150,151,166)$ and cytokine adjuvants $(89,90,112)$. These adjuvants should be further assessed, but future studies should also consider particulate adjuvants such as chitosan, virus-like particles, and immune stimulating complexes, and particulate adjuvants such as chitosan. These particulate adjuvants can simultaneously act as adjuvant and mucosal delivery system (180) and might contribute to the development of mucosal periodontal vaccines. Indeed, mucosal vaccine delivery systems represents a third unexploited source that could increase periodontal vaccine efficacy. Liposomes (90, 92, 94, 95, 116), bacterial outer membrane vesicles $(93,150,151)$, bacterial carriers (103, 105, 110, 139-142), and a viral carrier for DNA vaccination (91) have been successfully tested for mucosal delivery of periodontal vaccines in rodents. However, only liposomes (116) and polymer-based (113) delivery have been tested in dogs. Moreover, comparative data on the delivery systems are lacking and many other promising delivery systems, including lipid nanoparticles, have not yet been tested for mucosal vaccination against PD (167). Future research into $\mathrm{PD}$ vaccine delivery technology should also assess the expanding range of physical devices that localize vaccine release and/or mechanically disrupt mucosa for highly efficient delivery. Examples of highly suitable devices for mucosal PD vaccination in the oral cavity are microneedle arrays and mucoadhesive patches (181).

\section{DISCUSSION}

The reviewed data support the rationale behind mucosal PD vaccination as an adjunct to mechanical debridement for longterm PD control. Moreover, mucosal vaccination seems to be superior to systemic vaccination for the induction of protective immunity in the oral cavity. The reviewed preclinical studies used inactivated whole-cell vaccines, subunit vaccines, and DNA vaccines to induce immunity against $\mathrm{PD}$-associated pathogens. Most vaccines were administered intranasally or orally, but a few recent studies assessed the sublingual and intraocular route. Most PD vaccines targeted Porphyromonas gingivalis, while a few targeted Aggregatibacter actinomycetemcomitans, Fusobacterium nucleatum, or Eikenella corrodens. All studies found significant increases in antigen-specific antibodies, and those assessing clinical effects also observed reduced pathological manifestations (91, 100-115). While these data are encouraging, it should be noted that all but two studies $(113,116)$ used rodents, which have limited translational values.

Periodontal vaccines would complement mechanical debridement by promoting pathogen-specific bacterial clearance, blocking certain virulence factors, and shifting the immune response from destructive hyperinflammation to controlled homeostatic immunity. $P$. gingivalis seems to be a very promising candidate for periodontal vaccines, due to its disproportionately large influence on the microbial community and its role in the subversion and dysregulation of the host immune response (24). This keystone pathogen can impair the host immunity through manipulation of complement and Tolllike receptor function, subversion of neutrophils and macrophages, degradation of immunoglobulins and antimicrobial peptides, interactions with dendritic cells, and "local chemokine paralysis" in epithelial cells $(24,158,161)$. Successful vaccination against the involved virulence factors may prevent the dysregulation of the host's immune response and may contribute to oral eubiosis. Although P. gingivalis is only one of many bacteria implicated in periodontitis, specific immunity to this keystone pathogen has been linked to protection against clinical disease in animal models such as mice, rats and non-human primates (91, 100-104, 106-108, $111,112,114,115,124,182)$.

This review discusses several immunization strategies, presenting $P$. gingivalis gingipains as a promising vaccine target $(114,115,182)$. Gingipains (RgpA, RgpB, and Kgp) are proteases which play an important role in the colonization, interbacterial interactions, and immune subversion by $P$. gingivalis $(24,147,150)$. This is supported by the reduced alveolar bone destruction in mice and non-human primates with experimental periodontitis following vaccination that targets gingipains $(91,114,115,124,182)$. Another study assessed the effect of anti-gingipain egg yolk antibodies as an adjunct to non-surgical periodontal therapy in humans and 
found improved clinical outcomes when antibody-containing gel was administered into the periodontal pockets following scaling and root planing (183). Interestingly, gingipains are also produced by Porphyromonas gulae, a keystone pathogen in canine PD, and treatment with a Kgp inhibitor was reported to reduce gingival swelling and periodontal pockets in dogs with naturally occurring periodontitis (184). Overall, the aforementioned studies indicate that gingipains are promising vaccine targets, although more research is needed in appropriate PD models.

Our knowledge concerning the destructive and protective immune responses in $\mathrm{PD}$ is still incomplete. However, Thelper17 cells seem to be involved in periodontitis pathogenesis while T-helper 2 cells are associated with protective immune responses (185-187) Moreover, salivary SIgA seems to have an important role in the maintenance of oral symbiosis and homeostatic immunity (188). SIgA antibodies are produced as the major isotype on mucosal surfaces which limits the access of microorganisms and mucosal antigens to the mucosal barrier. Furthermore, SIgA regulates the important symbiotic relationship between commensals and the host (189). The preclinical data on periodontal vaccines supports the protective role of vaccine-induced salivary SIgA, although additional research is needed $(91,100,103-108,110-112,115)$. Considering that mucosal vaccination generally induces a stronger SIgA response than systemic immunization, the former may be more suited for vaccination against PD (88).

The potential for preventing and treating PD with mucosal periodontal vaccines is apparent, especially considering the recent progress in vaccinology which provides various opportunities. However, the available data is insufficient and difficult to interpret due to the use of rodent models. This demands further research into vaccine targets, formulations, and delivery systems via different mucosal vaccination routes. Moreover, the polymicrobial nature of PD calls for additional

\section{REFERENCES}

1. Armitage GC. Periodontal Diagnoses and Classification of Periodontal Diseases. Periodontol (2000) 2004:34:9-21. doi: 10.1046/j.09066713.2002.003421.x

2. Papapanou PN, Sanz M, Buduneli N, Dietrich T, Feres M, Fine DH, et al. Periodontitis: Consensus Report of Workgroup 2 of the 2017 World Workshop on the Classification of Periodontal and Peri-Implant Diseases and Conditions. J Periodontol (2018) 89:S173-82. doi: 10.1002/JPER.170721

3. World Health Organization. WHO Oral Health CAPP (Country/Area Profile Programme) . Available at: https://capp.mau.se/download/.

4. Bernabe E, Marcenes W, Hernandez CR, Bailey J, Abreu LG, Alipour V, et al. Global, Regional, and National Levels and Trends in Burden of Oral Conditions From 1990 to 2017: A Systematic Analysis for the Global Burden of Disease 2017 Study. J Dent Res (2020) 99(4):362-73. doi: 10.1177/ 0022034520908533

5. Bauer AE, Stella J, Lemmons M, Croney CC. Evaluating the Validity and Reliability of a Visual Dental Scale for Detection of Periodontal Disease (PD) in non-Anesthetized Dogs (Canis Familiaris). PloS One (2018) 13(9): e0203930. Carreira LM, editor. doi: 10.1371/journal.pone.0203930

6. Kortegaard HE, Eriksen T, Baelum V. Periodontal Disease in Research Beagle Dogs - an Epidemiological Study. J Small Anim Pract (2008) 49 (12):610-6. doi: 10.1111/j.1748-5827.2008.00609.x development and assessment of multivalent vaccines that can simultaneously induce antibodies against multiple pathogenic factors. These future studies should also reduce their reliance on rodent models, instead opting for more appropriate and clinically relevant animal models such as dogs, non-human primates or miniature pigs $(117,121)$.

In conclusion, there may be a sufficient rationale for mucosal vaccination against $P D$. However, the immunopathogenic complexity and polymicrobial aspect of $\mathrm{PD}$ appear to complicate the development of vaccines. Successful periodontal vaccines might require mucosal administration and a multivalent approach, which should be assessed in follow-up studies using appropriate animal models. Nevertheless, mucosal vaccination against $\mathrm{PD}$ appears feasible based on the available preclinical data.

\section{AUTHOR CONTRIBUTIONS}

$\mathrm{VV}$ and $\mathrm{BD}$ conceived the review article. VV wrote the manuscript in consultation with BA, BD, EC, and NS. All authors contributed to the article and approved the submitted version.

\section{FUNDING}

VV is supported by a $\mathrm{PhD}$ scholarship from Ghent University.

\section{ACKNOWLEDGMENTS}

The authors would like to thank Shireen Vanroelen for designing the illustration of this review article.

7. Queck KE, Chapman A, Herzog LJ, Shell-Martin T, Burgess-Cassler A, McClure GD. Oral-Fluid Thiol-Detection Test Identifies Underlying Active Periodontal Disease Not Detected by the Visual Awake Examination. J Am Anim Hosp Assoc (2018) 54(3):132-7. doi: 10.5326/JAAHA-MS-6607

8. Wallis C, Patel KV, Marshall M, Staunton R, Milella L, Harris S, et al. A Longitudinal Assessment of Periodontal Health Status in 53 Labrador Retrievers. J Small Anim Pract (2018) 59(9):560-9. doi: 10.1111/jsap.12870

9. Girard N, Servet E, Biourge V, Hennet P. Periodontal Health Status in a Colony of 109 Cats. J Vet Dent (2009) 26(3):147-55. doi: 10.1177/089875640902600301

10. Verhaert L, Van Wetter C. Survey of Oral Diseases in Cats in Flanders. Vlaams Diergeneeskd Tijdschr (2004) 73(5):331-40.

11. Colombo APV, Paster BJ, Grimaldi G, Lourenço TGB, Teva A, CamposNeto A, et al. Clinical and Microbiological Parameters of Naturally Occurring Periodontitis in the non-Human Primate Macaca Mulatta. J Oral Microbiol (2017) 9(1):1403843. doi: 10.1080/2000229720171403843

12. Friskopp J, Blomlöf L. Spontaneous Periodontitis in a Sample Group of the Monkey Macaca Fascicularis. J Periodontal Res (1988) 23(4):265-7. doi: 10.1111/j.1600-0765.1988.tb01370.x

13. Hajishengallis G, Chavakis T. Local and Systemic Mechanisms Linking Periodontal Disease and Inflammatory Comorbidities. Nat Rev Immunol (2021) 21(7):426-40. doi: 10.1038/s41577-020-00488-6

14. Liccardo D, Cannavo A, Spagnuolo G, Ferrara N, Cittadini A, Rengo C, et al. Periodontal Disease: A Risk Factor for Diabetes and Cardiovascular Disease. Int J Mol Sci (2019) 20(6):1414. doi: 10.3390/ijms20061414 
15. Ebersole JL, Cappelli D, Mathys EC, Steffen MJ, Singer RE, Montgomery M, et al. Periodontitis in Humans and Non-Human Primates: Oral-Systemic Linkage Inducing Acute Phase Proteins. Ann Periodontol (2002) 7(1):10211. doi: 10.1902/annals.2002.7.1.102

16. Cave NJ, Bridges JP, Thomas DG. Systemic Effects of Periodontal Disease in Cats. Vet Q (2012) 32(3-4):131-44. doi: 10.1080/01652176.2012.745957

17. Pereira dos Santos JD, Cunha E, Nunes T, Tavares L, Oliveira M. Relation Between Periodontal Disease and Systemic Diseases in Dogs. Res Vet Sci (2019) 125:136-40. doi: 10.1016/j.rvsc.2019.06.007

18. Glickman LT, Glickman NW, Moore GE, Goldstein GS, Lewis HB. Evaluation of the Risk of Endocarditis and Other Cardiovascular Events on the Basis of the Severity of Periodontal Disease in Dogs. J Am Vet Med Assoc (2009) 234(4):486-94. doi: 10.2460/javma.234.4.486

19. Glickman LT, Glickman NW, Moore GE, Lund EM, Lantz GC, Pressler BM. Association Between Chronic Azotemic Kidney Disease and the Severity of Periodontal Disease in Dogs. Prev Vet Med (2011) 99(2-4):193-200. doi: 10.1016/j.prevetmed.2011.01.011

20. Rawlinson JE, Goldstein RE, Reiter AM, Attwater DZ, Harvey CE. Association of Periodontal Disease With Systemic Health Indices in Dogs and the Systemic Response to Treatment of Periodontal Disease. J Am Vet Med Assoc (2011) 238(5):601-9. doi: 10.2460/javma.238.5.601

21. Brodala N, Merricks EP, Bellinger DA, Damrongsri D, Offenbacher S, Beck J, et al. Porphyromonas Gingivalis Bacteremia Induces Coronary and Aortic Atherosclerosis in Normocholesterolemic and Hypercholesterolemic Pigs. Arterioscler Thromb Vasc Biol (2005) 25(7):1446-51. doi: 10.1161/ 01.ATV.0000167525.69400.9c

22. Righolt AJ, Jevdjevic M, Marcenes W, Listl S. Global-, Regional-, and Country-Level Economic Impacts of Dental Diseases in 2015. J Dent Res (2018) 97(5):501-7. doi: 10.1177/0022034517750572

23. Hajishengallis G, Chavakis T, Lambris JD. Current Understanding of Periodontal Disease Pathogenesis and Targets for Host-Modulation Therapy. Periodontol 2000 (2020) 84(1):14-34. doi: 10.1111/prd.12331

24. Hajishengallis G, Lamont RJ. Polymicrobial Communities in Periodontal Disease: Their Quasi-Organismal Nature and Dialogue With the Host. Periodontol 2000 (2021) 86(1):210-30. doi: 10.1111/prd.12371

25. Maekawa T, Krauss JL, Abe T, Jotwani R, Triantafilou M, Triantafilou K, et al. Porphyromonas Gingivalis Manipulates Complement and TLR Signaling to Uncouple Bacterial Clearance From Inflammation and Promote Dysbiosis. Cell Host Microbe (2014) 15(6):768-78. doi: 10.1016/ j.chom.2014.05.012

26. Duran-Pinedo AE, Baker VD, Frias-Lopez J. The Periodontal Pathogen Porphyromonas Gingivalis Induces Expression of Transposases and Cell Death of Streptococcus Mitis in a Biofilm Model. Infect Immun (2014) 82 (8):3374-82. Blanke SR, editor. doi: 10.1128/IAI.01976-14

27. Frias-Lopez J, Duran-Pinedo A. Effect of Periodontal Pathogens on the Metatranscriptome of a Healthy Multispecies Biofilm Model. J Bacteriol (2012) 194(8):2082-95. doi: 10.1128/JB.06328-11

28. Hajishengallis G, Liang S, Payne MA, Hashim A, Jotwani R, Eskan MA, et al. Low-Abundance Biofilm Species Orchestrates Inflammatory Periodontal Disease Through the Commensal Microbiota and Complement. Cell Host Microbe (2011) 10(5):497-506. doi: 10.1016/j.chom.2011.10.006

29. Darveau RP. The Oral Microbial Consortium's Interaction With the Periodontal Innate Defense System. DNA Cell Biol (2009) 28(8):389-95. doi: 10.1089/dna.2009.0864

30. Ramsey MM, Whiteley M. Polymicrobial Interactions Stimulate Resistance to Host Innate Immunity Through Metabolite Perception. Proc Natl Acad Sci (2009) 106(5):1578-83. doi: 10.1073/pnas.0809533106

31. Park Y, Simionato MR, Sekiya K, Murakami Y, James D, Chen W, et al. Short Fimbriae of Porphyromonas Gingivalis and Their Role in Coadhesion With Streptococcus Gordonii. Infect Immun (2005) 73(7):3983-9. doi: 10.1128/ IAI.73.7.3983-3989.2005

32. Daep CA, Novak EA, Lamont RJ, Demuth DR. Structural Dissection and In Vivo Effectiveness of a Peptide Inhibitor of Porphyromonas Gingivalis Adherence to Streptococcus Gordonii. Infect Immun (2011) 79(1):67-74. doi: 10.1128/IAI.00361-10

33. Kuboniwa M, Tribble GD, James CE, Kilic AO, Tao L, Herzberg MC, et al. Streptococcus Gordonii Utilizes Several Distinct Gene Functions to Recruit
Porphyromonas Gingivalis Into a Mixed Community. Mol Microbiol (2006) 60(1):121-39. doi: 10.1111/j.1365-2958.2006.05099.x

34. Yost S, Duran-Pinedo AE, Teles R, Krishnan K, Frias-Lopez J. Functional Signatures of Oral Dysbiosis During Periodontitis Progression Revealed by Microbial Metatranscriptome Analysis. Genome Med (2015) 7(1):1-19. doi: 10.1186/s13073-015-0153-3

35. Zhang G, Rudney JD. Streptococcus Cristatus Attenuates Fusobacterium Nucleatum-Induced Cytokine Expression by Influencing Pathways Converging on Nuclear Factor-Kb. Mol Oral Microbiol (2011) 26(2):15063. doi: 10.1111/j.2041-1014.2010.00600.x

36. Xie H, Hong J, Sharma A, Wang B-Y. Streptococcus Cristatus ArcA Interferes With Porphyromonas Gingivalis Pathogenicity in Mice. J Periodontal Res (2012) 47(5):578-83. doi: 10.1111/j.1600-0765.2012.01469.x

37. Ho M-H, Lamont RJ, Xie H. Identification of Streptococcus Cristatus Peptides That Repress Expression of Virulence Genes in Porphyromonas Gingivalis. Sci Rep (2017) 7(1):1-11. doi: 10.1038/s41598-017-01551-4

38. Wang BY, Wu J, Lamont RJ, Lin X, Xie H. Negative Correlation of Distributions of Streptococcus Cristatus and Porphyromonas Gingivalis in Subgingival Plaque. J Clin Microbiol (2009) 47(12):3902-6. doi: 10.1128/ JCM.00072-09

39. Kinane DF, Stathopoulou PG, Papapanou PN. Periodontal Diseases. Nat Rev Dis Prim (2017) 3(1):17038. doi: 10.1038/nrdp.2017.38

40. Helal O, Göstemeyer G, Krois J, El Sayed KF, Graetz C, Schwendicke F. Predictors for Tooth Loss in Periodontitis Patients: Systematic Review and Meta-Analysis. J Clin Periodontol (2019) 46(7):699-712. doi: 10.1111/ jcpe.13118

41. Polak D, Wilensky A, Antonoglou GN, Shapira L, Goldstein M, Martin C. The Efficacy of Pocket Elimination/Reduction Compared to Access Flap Surgery: A Systematic Review and Meta-Analysis. J Clin Periodontol (2020) 47(S22):303-19. doi: 10.1111/jcpe.13246

42. Nibali L, Koidou VP, Nieri M, Barbato L, Pagliaro U, Cairo F. Regenerative Surgery Versus Access Flap for the Treatment of Intra-Bony Periodontal Defects: A Systematic Review and Meta-Analysis. J Clin Periodontol (2020) 47(S22):320-51. doi: 10.1111/jcpe.13237

43. Saglam M, Kantarci A, Dundar N, Hakki SS. Clinical and Biochemical Effects of Diode Laser as an Adjunct to Nonsurgical Treatment of Chronic Periodontitis: A Randomized, Controlled Clinical Trial. Lasers Med Sci (2012) 29(1):37-46. doi: 10.1007/s10103-012-1230-0

44. Hanes PJ, Purvis JP. Local Anti-Infective Therapy: Pharmacological Agents. A Syst Rev Ann Periodontol (2003) 8(1):79-98. doi: 10.1902/ annals.2003.8.1.79

45. Matesanz-Pérez P, García-Gargallo M, Figuero E, Bascones-Martínez A, Sanz M, Herrera D. A Systematic Review on the Effects of Local Antimicrobials as Adjuncts to Subgingival Debridement, Compared With Subgingival Debridement Alone, in the Treatment of Chronic Periodontitis. J Clin Periodontol (2013) 40(3):227-41. doi: 10.1111/jcpe.12026

46. Jepsen K, Jepsen S. Antibiotics/antimicrobials: Systemic and Local Administration in the Therapy of Mild to Moderately Advanced Periodontitis. Periodontol (2016) 71(1):82-112. doi: 10.1111/prd.12121

47. Ong A, Kim J, Loo S, Quaranta A, Rincon A JC. Prescribing Trends of Systemic Antibiotics by Periodontists in Australia. J Periodontol (2019) 90 (9):982-92. doi: 10.1002/JPER.18-0586

48. Preus HR, Fredriksen KW, Vogsland AE, Sandvik L, Grytten JI. AntibioticPrescribing Habits Among Norwegian Dentists: A Survey Over 25 Years (1990-2015). Eur J Oral Sci (2017) 125(4):280-7. doi: 10.1111/eos.12360

49. Cope AL, Francis NA, Wood F, Chestnutt IG. Antibiotic Prescribing in UK General Dental Practice: A Cross-Sectional Study. Community Dent Oral Epidemiol (2016) 44(2):145-53. doi: 10.1111/cdoe.12199

50. Germack M, Sedgley CM, Sabbah W, Whitten B. Antibiotic Use in 2016 by Members of the American Association of Endodontists: Report of a National Survey. J Endod (2017) 43(10):1615-22. doi: 10.1016/j.joen.2017.05.009

51. Koyuncuoglu CZ, Aydin M, Kirmizi NI, Aydin V, Aksoy M, Isli F, et al. Rational Use of Medicine in Dentistry: Do Dentists Prescribe Antibiotics in Appropriate Indications? Eur J Clin Pharmacol (2017) 73(8):1027-32. doi: 10.1007/s00228-017-2258-7

52. Dadgostar P. Antimicrobial Resistance: Implications and Costs. Infect Drug Resist (2019) 12:3903-10. doi: 10.2147/IDR.S234610 
53. Akrivopoulou C, Green IM, Donos N, Nair SP, Ready D. Aggregatibacter Actinomycetemcomitans Serotype Prevalence and Antibiotic Resistance in a UK Population With Periodontitis. J Glob Antimicrob Resist (2017) 10:54-8. doi: 10.1016/j.jgar.2017.03.011

54. Arredondo A, Blanc V, Mor C, Nart J, León R. Azithromycin and Erythromycin Susceptibility and Macrolide Resistance Genes in Prevotella From Patients With Periodontal Disease. Oral Dis (2019) 25(3):860-7. doi: 10.1111/odi.13043

55. Rams TE, Degener JE, van Winkelhoff AJ. Antibiotic Resistance in Human Chronic Periodontitis Microbiota. J Periodontol (2014) 85(1):160-9. doi: 10.1902/jop.2013.130142

56. Ardila CM, Bedoya-García JA. Antimicrobial Resistance of Aggregatibacter Actinomycetemcomitans, Porphyromonas Gingivalis and Tannerella Forsythia in Periodontitis Patients. J Glob Antimicrob Resist (2020) 22:215-8. doi: 10.1016/j.jgar.2020.02.024

57. Pérez-Serrano RM, Domínguez-Pérez RA, Ayala-Herrera JL, Luna-Jaramillo AE, Zaldivar-Lelo de Larrea G, Solís-Sainz JC, et al. Dental Plaque Microbiota of Pet Owners and Their Dogs as a Shared Source and Reservoir of Antimicrobial Resistance Genes. J Glob Antimicrob Resist (2020) 21:285-90. doi: 10.1016/j.jgar.2020.03.025

58. Rams TE, Sautter JD, van Winkelhoff AJ. Antibiotic Resistance of Human Periodontal Pathogen Parvimonas Micra Over 10 Years. Antibiot (2020) 9 (10):709. doi: 10.3390/antibiotics9100709

59. Rams TE, Sautter JD, van Winkelhoff AJ. Comparative In Vitro Resistance of Human Periodontal Bacterial Pathogens to Tinidazole and Four Other Antibiotics. Antibiot (2020) 9(2):68. doi: 10.3390/antibiotics9020068

60. Arredondo A, Blanc V, Mor C, Nart J, León R. Tetracycline and Multidrug Resistance in the Oral Microbiota: Differences Between Healthy Subjects and Patients With Periodontitis in Spain. J Oral Microbiol (2020) 13(1):1847431. doi: 10.1080/2000229720201847431

61. Almeida V de SM, Azevedo J, Leal HF, de Queiroz ATL, Filho HPdaS, Reis JN. Bacterial Diversity and Prevalence of Antibiotic Resistance Genes in the Oral Microbiome. PloS One (2020) 15(9):e0239664. doi: 10.1371/ journal.pone. 0239664

62. Arredondo A, Blanc V, Mor C, Nart J, León R. Resistance to $\beta$-Lactams and Distribution of $\beta$-Lactam Resistance Genes in Subgingival Microbiota From Spanish Patients With Periodontitis. Clin Oral Investig (2020) 24(12):463948. doi: 10.1007/s00784-020-03333-1

63. Jepsen K, Falk W, Brune F, Fimmers R, Jepsen S, Bekeredjian-Ding I. Prevalence and Antibiotic Susceptibility Trends of Periodontal Pathogens in the Subgingival Microbiota of German Periodontitis Patients: A Retrospective Surveillance Study. J Clin Periodontol (2021) 48(9):1216-27. doi: $10.1111 /$ jcpe. 13468

64. Poetker DM, Reh DD. A Comprehensive Review of the Adverse Effects of Systemic Corticosteroids. Otolaryngol Clin North Am (2010) 43(4):753-68. doi: $10.1016 /$ j.otc.2010.04.003

65. Harirforoosh S, Asghar W, Jamali F. Adverse Effects of Nonsteroidal Antiinflammatory Drugs: An Update of Gastrointestinal, Cardiovascular and Renal Complications. J Pharm Pharm Sci (2014) 16(5):821. doi: 10.18433/J3VW2F

66. Salvi G, Lang N. The Effects of Non-Steroidal Anti-Inflammatory Drugs (Selective and Non-Selective) on the Treatment of Periodontal Diseases. Curr Pharm Des (2005) 11(14):1757-69. doi: 10.2174/1381612053764878

67. Safkan B, Knuuttila M. Corticosteroid Therapy and Periodontal Disease. J Clin Periodontol (1984) 11(8):515-22. doi: 10.1111/j.1600-051X.1984.tb00903.x

68. Serhan CN, Jain A, Marleau S, Clish C, Kantarci A, Behbehani B, et al. Reduced Inflammation and Tissue Damage in Transgenic Rabbits Overexpressing 15-Lipoxygenase and Endogenous Anti-Inflammatory Lipid Mediators. J Immunol (2003) 171(12):6856-65. doi: 10.4049/ jimmunol.171.12.6856

69. Hasturk H, Kantarci A, Goguet-Surmenian E, Blackwood A, Andry C, Serhan CN, et al. Resolvin E1 Regulates Inflammation at the Cellular and Tissue Level and Restores Tissue Homeostasis In Vivo. J Immunol (2007) 179(10):7021-9. doi: 10.4049/jimmunol.179.10.7021

70. Hasturk H, Kantarci A, Ohira T, Arita M, Ebrahimi N, Chiang N, et al. RvE1 Protects From Local Inflammation and Osteoclastmediated Bone Destruction in Periodontitis. FASEB J (2006) 20(2):401-3. doi: 10.1096/ fj.05-4724fje
71. Van Dyke TE, Hasturk H, Kantarci A, Freire MO, Nguyen D, Dalli J, et al. Proresolving Nanomedicines Activate Bone Regeneration in Periodontitis. J Dent Res (2015) 94(1):148-56. doi: 10.1177/0022034514557331

72. Hasturk H, Abdallah R, Kantarci A, Nguyen D, Giordano N, Hamilton J, et al. Resolvin E1 (RvE1) Attenuates Atherosclerotic Plaque Formation in Diet and Inflammation-Induced Atherogenesis. Arterioscler Thromb Vasc Biol (2015) 35(5):1123-33. doi: 10.1161/ATVBAHA.115.305324

73. Lee C-T, Teles R, Kantarci A, Chen T, McCafferty J, Starr JR, et al. Resolvin E1 Reverses Experimental Periodontitis and Dysbiosis. J Immunol (2016) 197(7):2796-806. doi: 10.4049/jimmunol.1600859

74. Abe T, Hosur KB, Hajishengallis E, Reis ES, Ricklin D, Lambris JD, et al. Local Complement-Targeted Intervention in Periodontitis: Proof-OfConcept Using a C5a Receptor (CD88) Antagonist. J Immunol (2012) 189 (11):5442-8. doi: 10.4049/jimmunol.1202339

75. Maekawa T, Abe T, Hajishengallis E, Hosur KB, DeAngelis RA, Ricklin D, et al. Genetic and Intervention Studies Implicating Complement C3 as a Major Target for the Treatment of Periodontitis. J Immunol (2014) 192 (12):6020-7. doi: 10.4049/jimmunol.1400569

76. Maekawa T, Briones RA, Resuello RRG, Tuplano JV, Hajishengallis E, Kajikawa T, et al. Inhibition of Pre-Existing Natural Periodontitis in nonHuman Primates by a Locally Administered Peptide Inhibitor of Complement C3. J Clin Periodontol (2016) 43(3):238-49. doi: 10.1111/ jcpe. 12507

77. Kajikawa T, Briones RA, Resuello RRG, Tuplano JV, Reis ES, Hajishengallis E, et al. Safety and Efficacy of the Complement Inhibitor AMY-101 in a Natural Model of Periodontitis in Non-Human Primates. Mol Ther Methods Clin Dev (2017) 6:207-15. doi: 10.1016/j.omtm.2017.08.001

78. Delima AJ, Karatzas S, Amar S, Graves DT. Inflammation and Tissue Loss Caused by Periodontal Pathogens Is Reduced by Interleukin-1 Antagonists. J Infect Dis (2002) 186(4):511-6. doi: 10.1086/341778

79. Delima AJ, Oates T, Assuma R, Schwartz Z, Cochran D, Amar S, et al. Soluble Antagonists to Interleukin-1 (IL-1) and Tumor Necrosis Factor (TNF) Inhibits Loss of Tissue Attachment in Experimental Periodontitis. J Clin Periodontol (2001) 28(3):233-40. doi: 10.1034/j.1600-051x.2001.028003233.x

80. Assuma R, Oates T, Cochran D, Amar S, Graves DT. IL-1 and TNF Aantagonists Inhibit the Inflammatory Response and Bone Loss in Experimental Periodontitis. J Immunol (1998) 160(1):403-09.

81. Di Paola R, Mazzon E, Muià C, Crisafulli C, Terrana D, Greco S, et al. Effects of Etanercept, a Tumour Necrosis Factor- $\alpha$ Antagonist, in an Experimental Model of Periodontitis in Rats. Br J Pharmacol (2007) 150(3):286-97. doi: 10.1038/sj.bjp.0706979

82. Eskan MA, Jotwani R, Abe T, Chmelar J, Lim J-H, Liang S, et al. The Leukocyte Integrin Antagonist Del-1 Inhibits IL-17-Mediated Inflammatory Bone Loss. Nat Immunol (2012) 13(5):465-73. doi: 10.1038/ni.2260

83. Oates TW, Graves DT, Cochran DL. Clinical, Radiographic and Biochemical Assessment of IL-1/TNF- $\alpha$ Antagonist Inhibition of Bone Loss in Experimental Periodontitis. J Clin Periodontol (2002) 29(2):137-43. doi: 10.1034/j.1600-051x.2002.290208.x

84. Gonçalves DC, Evangelista RC, da Silva RR, Santos MJS, Silva FS, Aragão KS, et al. Infliximab Attenuates Inflammatory Osteolysis in a Model of Periodontitis in Wistar Rats. Exp Biol Med (2014) 239(4):442-53. doi: $10.1177 / 1535370213520114$

85. Brandtzaeg P. Secretory Immunity With Special Reference to the Oral Cavity. J Oral Microbiol (2013) 5(1):20401. doi: 10.3402/jom.v5i0.20401

86. Hirschfeld I. An Investigation of Inava Endocorps Vaccine ${ }^{*}$ Report of the Committee on Scientific Research. Read Before the American Academy of Periodontology, Louisville, Ky., Sept. 18, 1925. J Am Dent Assoc (1926) 13 (11):1613-24. doi: 10.14219/jada.archive.1926.0265

87. Pfizer Animal Health. The Porphyromonas Denticanis-Gulae-Salivosa Bacterin Will No Longer be Available. (2011).

88. Kurita-Ochiai T, Hashizume-Takizawa T, Kobayashi R, Yamamoto M. Mucosal Vaccines for Oral Disease. In: Mucosal Vaccines. Amsterdam: Elsevier (2020). p. 649-61.

89. Guo H, Wang X, Jiang G, Yang P. Construction of a Siga-Enhancing AntiPorphyromonas Gingivalis FimA Vaccine and Nasal Immunization in Mice. Immunol Lett (2006) 107(1):71-5. doi: 10.1016/j.imlet.2006.07.008

90. Honma K, Kato T, Okuda K. Salivary Immunoglobulin A Production Against a Synthetic Oligopeptide Antigen of Actinobacillus 
Actinomycetemcomitans Fimbriae. Oral Microbiol Immunol (1999) 14 (5):288-92. doi: 10.1034/j.1399-302X.1999.140504.x

91. Miyachi K, Ishihara K, Kimizuka R, Okuda K. Arg-Gingipain A DNA Vaccine Prevents Alveolar Bone Loss in Mice. J Dent Res (2007) 86(5):44650. doi: 10.1177/154405910708600511

92. Kusumoto Y, Ogawa T, Hamada S. Generation of Specific AntibodySecreting Cells in Salivary Glands of BALB/c Mice Following Parenteral or Oral Immunization With Porphyromonas Gingivalis Fimbriae. Arch Oral Biol (1993) 38(5):361-7. doi: 10.1016/0003-9969(93)90206-2

93. Nakao R, Hasegawa H, Dongying B, Ohnishi M, Senpuku H. Assessment of Outer Membrane Vesicles of Periodontopathic Bacterium Porphyromonas Gingivalis as Possible Mucosal Immunogen. Vaccine (2016) 34(38):4626-34. doi: 10.1016/j.vaccine.2016.06.016

94. Ogawa T, Kusumoto Y, Kiyono H, McGhee JR, Hamada S. Occurrence of Antigen-Specific B Cells Following Oral or Parenteral Immunization With Porphyromonas Gingivalis Fimbriae. Int Immunol (1992) 4(9):1003-10. doi: 10.1093/intimm/4.9.1003

95. Ogawa T, Shimauchi H, Hamada S. Mucosal and Systemic Immune Responses in BALB/c Mice to Bacteroides Gingivalis Fimbriae Administered Orally. Infect Immun (1989) 57(11):3466-71. doi: 10.1128/ iai.57.11.3466-3471.1989

96. Okuda K, Kato T, Naito Y, Takazoe I, Kikuchi Y, Nakamura T, et al. Protective Efficacy of Active and Passive Immunizations Against Experimental Infection With Bacteroides Gingivalis in Ligated Hamsters. J Dent Res (1988) 67(5):807-11. doi: 10.1177/00220345880670050201

97. Takamatsu-Matsushita N, Yamaguchi N, Kawasaki M, Yamashita Y, Takehara T, Koga T. Immunogenicity of Actinobacillus Actinomycetemcomitans Serotype B-Specific Polysaccharide-Protein Conjugate. Oral Microbiol Immunol (1996) 11(4):220-5. doi: 10.1111/j.1399-302X.1996.tb00173.x

98. Zhang P, Yang QB, Marciani DJ, Martin M, Clements JD, Michalek SM, et al. Effectiveness of the Quillaja Saponin Semi-Synthetic Analog GPI-0100 in Potentiating Mucosal and Systemic Responses to Recombinant HagB From Porphyromonas Gingivalis. Vaccine (2003) 21(27-30):4459-71. doi: 10.1016/S0264-410X(03)00438-9

99. Zhang P, Yang Q-B, Balkovetz DF, Lewis JP, Clements JD, Michalek SM, et al. Effectiveness of the B Subunit of Cholera Toxin in Potentiating Immune Responses to the Recombinant Hemagglutinin/Adhesin Domain of the Gingipain Kgp From Porphyromonas Gingivalis. Vaccine (2005) 23 (39):4734-44. doi: 10.1016/j.vaccine.2005.05.004

100. Takahashi Y, Kumada H, Hamada N, Haishima Y, Ozono S, Isaka M, et al. Induction of Immune Responses and Prevention of Alveolar Bone Loss by Intranasal Administration of Mice With Porphyromonas Gingivalis Fimbriae and Recombinant Cholera Toxin B Subunit. Oral Microbiol Immunol (2007) 22(6):374-80. doi: 10.1111/j.1399-302X.2007.00373.x

101. Chang E, Kobayashi R, Hagiwara-Hamano M, Kurita-Ochiai T, Komiya M. Nasal Vaccination With GroEL Plus CpG ODN Inhibits P. GingivalisInduced Inflammation and Alveolar Bone Loss. Int J Oral-Med Sci (2020) 18(3-4):191-8. doi: 10.5466/ijoms.18.191

102. Bai G, Yu H, Guan X, Zeng F, Liu X, Chen B, et al. CpG Immunostimulatory Oligodeoxynucleotide 1826 as a Novel Nasal ODN Adjuvant Enhanced the Protective Efficacy of the Periodontitis Gene Vaccine in a Periodontitis Model in SD Rats. BMC Oral Heal (2021) 21(1):1-12. doi: 10.1186/s12903-021-01763-1

103. Sharma A, Honma K, Evans RT, Hruby DE, Genco RJ. Oral Immunization With Recombinant Streptococcus Gordonii Expressing Porphyromonas Gingivalis FimA Domains. Infect Immun (2001) 69(5):2928-34. DiRita VJ, editor. doi: 10.1128/IAI.69.5.2928-2934.2001

104. Liu C, Hashizume T, Kurita-Ochiai T, Fujihashi K, Yamamoto M. Oral Immunization With Porphyromonas Gingivalis Outer Membrane Protein and CpG Oligodeoxynucleotides Elicits T Helper 1 and 2 Cytokines for Enhanced Protective Immunity. Mol Oral Microbiol (2010) 25(3):178-89. doi: 10.1111/j.2041-1014.2009.00560.x

105. Ma L, Ding Q, Feng X, Li F. The Protective Effect of Recombinant FomAExpressing Lactobacillus Acidophilus Against Periodontal Infection. Inflammation (2013) 36(5):1160-70. doi: 10.1007/s10753-013-9651-x

106. Zhang T, Hashizume T, Kurita-Ochiai T, Yamamoto M. Sublingual Vaccination With Outer Membrane Protein of Porphyromonas Gingivalis and Flt3 Ligand Elicits Protective Immunity in the Oral Cavity. Biochem Biophys Res Commun (2009) 390(3):937-41. doi: 10.1016/j.bbrc.2009.10.081
107. Yuzawa S, Kurita-Ochiai T, Hashizume T, Kobayashi R, Abiko Y, Yamamoto M. Sublingual Vaccination With Fusion Protein Consisting of the Functional Domain of Hemagglutinin A of Porphyromonas Gingivalis and Escherichia Coli Maltose-Binding Protein Elicits Protective Immunity in the Oral Cavity. FEMS Immunol Med Microbiol (2012) 64(2):265-72. doi: 10.1111/j.1574695X.2011.00895.x

108. Momoi F, Hashizume T, Kurita-Ochiai T, Yuki Y, Kiyono H, Yamamoto M. Nasal Vaccination With the 40-Kilodalton Outer Membrane Protein of Porphyromonas Gingivalis and a Nontoxic Chimeric Enterotoxin Adjuvant Induces Long-Term Protective Immunity With Reduced Levels of Immunoglobulin E Antibodies. Infect Immun (2008) 76(6):2777-84. doi: 10.1128/IAI.01502-07

109. Liu PF, Haake SK, Gallo RL, Huang CM. A Novel Vaccine Targeting Fusobacterium Nucleatum Against Abscesses and Halitosis. Vaccine (2009) 27(10):1589-95. doi: 10.1016/j.vaccine.2008.12.058

110. Liu PF, Shi W, Zhu W, Smith JW, Hsieh SL, Gallo RL, et al. Vaccination Targeting Surface FomA of Fusobacterium Nucleatum Against Bacterial CoAggregation: Implication for Treatment of Periodontal Infection and Halitosis. Vaccine (2010) 28(19):3496-505. doi: 10.1016/j.vaccine.2010.02.047

111. Du Y, Hashizume T, Kurita-Ochiai T, Yuzawa S, Abiko Y, Yamamoto M. Nasal Immunization With a Fusion Protein Consisting of the Hemagglutinin A Antigenic Region and the Maltose-Binding Protein Elicits CD11c+ CD8+ Dendritic Cells for Induced Long-Term Protective Immunity. Blanke $S R$ editor Infect Immun (2011) 79(2):895-904. doi: 10.1128/IAI.01203-10

112. Yu F, Xu Q-A, Chen W. A Targeted fimA DNA Vaccine Prevents Alveolar Bone Loss in Mice After Intra-Nasal Administration. J Clin Periodontol (2011) 38(4):334-40. doi: 10.1111/j.1600-051X.2010.01700.x

113. Peters JL, DeMars PL, Collins LM, Stoner JA, Matsumoto H, Komori N, et al. Effects of Immunization With Natural and Recombinant Lysine Decarboxylase on Canine Gingivitis Development. Vaccine (2012) 30 (47):6706-12. doi: 10.1016/j.vaccine.2012.08.028

114. Puth S, Hong SH, Na HS, Lee HH, Lee YS, Kim SY, et al. A Built-in Adjuvant-Engineered Mucosal Vaccine Against Dysbiotic Periodontal Diseases. Mucosal Immunol (2019) 12(2):565-79. doi: 10.1038/s41385-0180104-6

115. Puth S, Hong H, Park MJ, Lee HH, Lee YS, Jeong K, et al. Mucosal Immunization With a Flagellin-Adjuvanted Hgp44 Vaccine Enhances Protective Immune Responses in a Murine Porphyromonas Gingivalis Infection Model. Hum Vaccin Immunother (2017) 13:2794-803. doi: 10.1080/21645515.2017.1327109

116. Shimizu Y, Iwasaki T, Tajima T, Yuba E, Kono K, Watarai S. Induction of Antibody Response in the Oral Cavity of Dogs Following Intraocular (Eye Drop) Immunization With Porphyromonas Gingivalis Cell Lysate Incorporated in pH-Sensitive Fusogenic Polymer-Modified Liposomes. $J$ Vet Med Sci (2017) 79(2):290-8. doi: 10.1292/jvms.16-0338

117. Albuquerque C, Morinha F, Requicha J, Martins T, Dias I, Guedes-Pinto H, et al. Canine Periodontitis: The Dog as an Important Model for Periodontal Studies. Vet J (2012) 191(3):299-305. doi: 10.1016/j.tvjl.2011.08.017

118. Catunda RQ, Ho KK-Y, Patel S, Febbraio M. A 2-Plane Micro-Computed Tomographic Alveolar Bone Measurement Approach in Mice. Imaging Sci Dent (2021) 51:e47. doi: 10.5624/isd.20210058

119. Lohrberg M, Pabst R, Wilting J. Co-Localization of Lymphoid Aggregates and Lymphatic Networks in Nose- (NALT) and Lacrimal Duct-Associated Lymphoid Tissue (LDALT) of Mice. BMC Immunol (2018) 19(1):1-8. doi: 10.1186/s12865-018-0242-3

120. Casteleyn C, Breugelmans S, Simoens P, Van Den Broeck W. The Tonsils Revisited: Review of the Anatomical Localization and Histological Characteristics of the Tonsils of Domestic and Laboratory Animals. Clin Dev Immunol (2011) 2011:472460. doi: 10.1155/2011/472460

121. Yang J, Dai L, Yu Q, Yang Q. Histological and Anatomical Structure of the Nasal Cavity of Bama Minipigs. PloS One (2017) 12(3):e0173902. doi: 10.1371/journal.pone.0173902

122. Roberts FA, Houston LS, Lukehart SA, Mancl LA, Persson GR, Page RC. Periodontitis Vaccine Decreases Local Prostaglandin E2 Levels in a Primate Model. Infect Immun (2004) 72(2):1166. doi: 10.1128/IAI.72.2.11661168.2004

123. Persson GR, Engel D, Whitney C, Darveau R, Weinberg A, Brunsvold M, et al. Immunization Against Porphyromonas Gingivalis Inhibits Progression 
of Experimental Periodontitis in Nonhuman Primates. Infect Immun (1994) 62(3):1026-31. doi: 10.1128/iai.62.3.1026-1031.1994

124. Page RC, Lantz MS, Darveau R, Jeffcoat M, Mancl L, Houston L, et al. Immunization of Macaca Fascicularis Against Experimental Periodontitis Using a Vaccine Containing Cysteine Proteases Purified From Porphyromonas Gingivalis. Oral Microbiol Immunol (2007) 22(3):162-8. doi: 10.1111/j.1399-302X.2007.00337.x

125. Struillou X, Boutigny H, Soueidan A, Layrolle P. Experimental Animal Models in Periodontology: A Review. Open Dent J (2010) 4(1):37-47. doi: $10.2174 / 1874210601004010037$

126. Hardham J, Reed M, Wong J, King K, Laurinat B, Sfintescu C, et al. Evaluation of a Monovalent Companion Animal Periodontal Disease Vaccine in an Experimental Mouse Periodontitis Model. Vaccine (2005) 23 (24):3148-56. doi: 10.1016/j.vaccine.2004.12.026

127. Hardham J, Sfintescu C, Evans RT. Evaluation of Cross-Protection by Immunization With an Experimental Trivalent Companion Animal Periodontitis Vaccine in the Mouse Periodontitis Model. J Vet Dent (2008) 25(1):23-7. doi: 10.1177/089875640802500107

128. Liu Y, Zheng Y, Ding G, Fang D, Zhang C, Bartold PM, et al. Periodontal Ligament Stem Cell-Mediated Treatment for Periodontitis in Miniature Swine. Stem Cells (2008) 26(4):1065-73. doi: 10.1634/stemcells.2007-0734

129. Sasaki Y, Hayashi J, Fujimura T, Iwamura Y, Yamamoto G, Nishida E, et al. New Irradiation Method With Indocyanine Green-Loaded Nanospheres for Inactivating Periodontal Pathogens. Int J Mol Sci (2017) 18(1):154. doi: $10.3390 /$ ijms 18010154

130. Abe T, Hajishengallis G. Optimization of the Ligature-Induced Periodontitis Model in Mice. J Immunol Methods (2013) 394(1-2):49-54. doi: 10.1016/ j.jim.2013.05.002

131. Russell MW, Mestecky J. Mucosal Vaccines: An Overview. In: Mucosal Immunology, 4th ed. Amsterdam: Elsevier Inc (2015). p. 1039-46.

132. Wilson HL, Gerdts V, Babiuk LA. Mucosal Vaccine Development for Veterinary and Aquatic Diseases. In: Mucosal Vaccines: Innovation for Preventing Infectious Diseases. Amsterdam: Elsevier (2019). p. 811-29.

133. Vela Ramirez JE, Sharpe LA, Peppas NA. Current State and Challenges in Developing Oral Vaccines. Adv Drug Deliv Rev (2017) 114:116-31. doi: 10.1016/j.addr.2017.04.008

134. Devriendt B, De Geest BG, Goddeeris BM, Cox E. Crossing the Barrier: Targeting Epithelial Receptors for Enhanced Oral Vaccine Delivery. J Controlled Release (2012) 160:431-9. Elsevier;. doi: 10.1016/j.jconrel.2012. 02.006

135. Van der Weken H, Cox E, Devriendt B. Advances in Oral Subunit Vaccine Design. Vaccines (2021) 9(1):1. doi: 10.3390/vaccines9010001

136. Yanagita $M$, Hiroi $T$, Kitagaki $N$, Hamada $S$, Ito $H$, Shimauchi $H$, et al. Nasopharyngeal-Associated Lymphoreticular Tissue (NALT) Immunity: Fimbriae-Specific Th1 and Th2 Cell-Regulated IgA Responses for the Inhibition of Bacterial Attachment to Epithelial Cells and Subsequent Inflammatory Cytokine Production. J Immunol (1999) 162(6):3559-65.

137. Nagasawa T, Aramaki M, Takamatsu N, Koseki T, Kobayashi H, Ishikawa I. Oral Administration of Porphyromonas Gingivalis Fimbriae With Cholera Toxin Induces Anti-Fimbriae Serum IgG, IgM, IgA and Salivary IgA Antibodies. J Periodontal Res (1999) 34(3):169-74. doi: 10.1111/j.16000765.1999.tb02238.x

138. Kim TG, Huy NX, Kim MY, Jeong DK, Jang YS, Yang MS, et al. Immunogenicity of a Cholera Toxin B Subunit Porphyromonas Gingivalis Fimbrial Antigen Fusion Protein Expressed in E. Coli. Mol Biotechnol (2009) 41(2):157-64. doi: 10.1007/s12033-008-9102-3

139. Kozarov E, Miyashita N, Burks J, Cerveny K, Brown TA, McArthur WP, et al. Expression and Immunogenicity of Hemagglutinin A From Porphyromonas Gingivalis in an AvirulentSalmonella Enterica Serovar Typhimurium Vaccine Strain. Infect Immun (2000) 68(2):732-9. Burns DL, editor. doi: 10.1128/IAI.68.2.732-739.2000

140. Dusek DM, Progulske-Fox A, Brown TA. Systemic and Mucosal Immune Responses in Mice Orally Immunized With Avirulent Salmonella Typhimurium Expressing a Cloned Porphyromonas Gingivalis Hemagglutinin. Infect Immun (1994) 62(5):1652-7. doi: 10.1128/ iai.62.5.1652-1657.1994

141. Isoda R, Simanski SP, Pathangey L, Stone AES, Brown TA. Expression of a Porphyromonas Gingivalis Hemagglutinin on the Surface of a Salmonella
Vaccine Vector. Vaccine (2007) 25(1):117-26. doi: 10.1016/ j.vaccine.2006.06.085

142. Kohler JJ, Pathangey LB, Brown TA. Oral Immunization With Recombinant Salmonella Typhimurium Expressing a Cloned Porphyromonas Gingivalis Hemagglutinin: Effect of Boosting on Mucosal, Systemic and Immunoglobulin G Subclass Response. Oral Microbiol Immunol (1998) 13 (2):81-8. doi: 10.1111/j.1399-302X.1998.tb00717.x

143. Ikeda T, Kobayashi R, Kurita-Ochiai T. Comparison of Mucosal Immune Response After Oral, Nasal or Sublingual Immunization With an Outer Membrane Protein of Porphyromonas Gingivalis. Int J Oral-Med Sci (2013) 12(3):121-8. doi: 10.5466/ijoms.12.121

144. van Ginkel FW, Jackson RJ, Yuki Y, McGhee JR. Cutting Edge: The Mucosal Adjuvant Cholera Toxin Redirects Vaccine Proteins Into Olfactory Tissues. J Immunol (2000) 165(9):4778-82. doi: 10.4049/jimmunol.165.9.4778

145. Lewis DJM, Huo Z, Barnett S, Kromann I, Giemza R, Galiza E, et al. Transient Facial Nerve Paralysis (Bell's Palsy) Following Intranasal Delivery of a Genetically Detoxified Mutant of Escherichia Coli Heat Labile Toxin. PloS One (2009) 4(9):e6999. Bereswill S, editor. doi: 10.1371/ journal.pone.0006999

146. Nakagaki H, Sekine S, Terao Y, Toe M, Tanaka M, Ito H-O, et al. Fusobacterium Nucleatum Envelope Protein FomA Is Immunogenic and Binds to the Salivary Statherin-Derived Peptide. Infect Immun (2010) 78 (3):1185-92. doi: 10.1128/IAI.01224-09

147. Kobuchi K, Kataoka K, Taguchi Y, Miyake T, Umeda M. Nasal Double DNA Adjuvant Induces Salivary FimA-Specific Secretory IgA Antibodies in Young and Aging Mice and Blocks Porphyromonas Gingivalis Binding to a Salivary Protein. BMC Oral Health (2019) 19(1):188. doi: 10.1186/s12903-019-0886-2

148. Namikoshi J, Otake S, Maeba S, Hayakawa M, Abiko Y, Yamamoto M. Specific Antibodies Induced by Nasally Administered 40-kDa Outer Membrane Protein of Porphyromonas Gingivalis Inhibits Coaggregation Activity of P. Gingivalis. Vaccine (2003) 22(2):250-6. doi: 10.1016/S0264410X(03)00576-0

149. Cai Y, Kurita-Ochiai T, Kobayashi R, Hashizume T, Yamamoto M. Nasal Immunization With the $40-\mathrm{kDa}$ Outer Membrane Protein of Porphyromonas Gingivalis Plus Cholera Toxin Induces Protective Immunity in Aged Mice. J Oral Sci (2013) 55(2):107-14. doi: 10.2334/ josnusd.55.107

150. Bai D, Nakao R, Ito A, Uematsu H, Senpuku H. Immunoreactive Antigens Recognized in Serum Samples From Mice Intranasally Immunized With Porphyromonas Gingivalis Outer Membrane Vesicles. Pathog Dis (2015) 73 (3):6. doi: 10.1093/femspd/ftu006

151. Nakao R, Hasegawa H, Ochiai K, Takashiba S, Ainai A, Ohnishi M, et al. Outer Membrane Vesicles of Porphyromonas Gingivalis Elicit a Mucosal Immune Response. PloS One (2011) 6(10):e26163. Chin W-C, editor. doi: 10.1371/journal.pone.0026163

152. Yang Q-B, Martin M, Michalek SM, Katz J. Mechanisms of Monophosphoryl Lipid A Augmentation of Host Responses to Recombinant HagB From Porphyromonas Gingivalis. Infect Immun (2002) 70(7):3557-65. doi: 10.1128/IAI.70.7.3557-3565.2002

153. Zhang P, Lewis JP, Michalek SM, Katz J. Role of CD80 and CD86 in Host Immune Responses to the Recombinant Hemagglutinin Domain of Porphyromonas Gingivalis Gingipain and in the Adjuvanticity of Cholera Toxin B and Monophosphoryl Lipid a. Vaccine (2007) 25(33):6201-10. doi: 10.1016/j.vaccine.2007.05.066

154. Pabst R. Mucosal Vaccination by the Intranasal Route. Nose-Associated Lymphoid Tissue (NALT)-Structure, Function and Species Differences. Vaccine (2015) 33:4406-13. . Elsevier Ltd;. doi: 10.1016/j.vaccine.2015.07.022

155. Kiros TG, Levast B, Auray G, Strom S, Van Kessel J, Gerdts V. The Importance of Animal Models in the Development of Vaccines. In: Innovation in Vaccinology: From Design, Through to Delivery and Testing. Dordrecht: Springer Netherlands (2012). p. 251-64.

156. Seers CA, Mahmud ASM, Huq NL, Cross KJ, Reynolds EC. Porphyromonas Gingivalis Laboratory Strains and Clinical Isolates Exhibit Different Distribution of Cell Surface and Secreted Gingipains. J Oral Microbiol (2021) 13(1):1858001. doi: 10.1080/20002297.2020.1858001

157. Zhang L, Veith PD, Huq NL, Chen Y-Y, Seers CA, Cross KJ, et al. Porphyromonas Gingivalis Gingipains Display Transpeptidation Activity. J Proteome Res (2018) 17(8):2803-18. doi: 10.1021/acs.jproteome.8b00286 
158. Vincents B, Guentsch A, Kostolowska D, von Pawel-Rammingen U, Eick S, Potempa J, et al. Cleavage of IgG1 and IgG3 by Gingipain K From Porphyromonas Gingivalis may Compromise Host Defense in Progressive Periodontitis. FASEB J (2011) 25(10):3741-50. doi: 10.1096/fj.11-187799

159. Travis J, Pike R, Imamura T, Potempa J. Porphyromonas Gingivalis Proteinases as Virulence Factors in the Development of Periodontitis. J Periodontal Res (1997) 32(1 PART 2):120-5. doi: 10.1111/j.1600-0765.1997.tb01392.x

160. O'Brien-Simpson N, Veith P, Dashper S, Reynolds E. Porphyromonas Gingivalis Gingipains: The Molecular Teeth of a Microbial Vampire. Curr Protein Pept Sci (2005) 4(6):409-26. doi: 10.2174/1389203033487009

161. Abe N, Kadowaki T, Okamoto K, Nakayama K, Ohishi M, Yamamoto K. Biochemical and Functional Properties of Lysine-Specific Cysteine Proteinase (Lys-Gingipain) as a Virulence Factor of Porphyromonas Gingivalis in Periodontal Disease 1. J Biochem (1998) 123:305-12. doi: 10.1093/oxfordjournals.jbchem.a021937

162. Rhee JH. Current and New Approaches for Mucosal Vaccine Delivery. In: Mucosal Vaccines: Innovation for Preventing Infectious Diseases. Amsterdam: Elsevier (2020). p. 325-56.

163. Paris AL, Colomb E, Verrier B, Anjuère F, Monge C. Sublingual Vaccination and Delivery Systems. J Control Release (2021) 332:553-62. doi: 10.1016/ j.jconrel.2021.03.017

164. Kraan H, Vrieling H, Czerkinsky C, Jiskoot W, Kersten G, Amorij J-PP. Buccal and Sublingual Vaccine Delivery. J Control Release (2014) 190:58092. doi: 10.1016/j.jconrel.2014.05.060

165. Moffatt K, Wang Y, Raj Singh TR, Donnelly RF. Microneedles for Enhanced Transdermal and Intraocular Drug Delivery. Curr Opin Pharmacol (2017) 36:14-21. doi: 10.1016/j.coph.2017.07.007

166. Chang E, Kobayashi R, Hagiwara M, Komiya M, Kurita-Ochiai T, KuritaOchiai T. Evaluation of Suitable Antigens and Adjuvant Concentration for Sublingual Immunization to Prevent Periodontal Disease. Oral Sci Int (2019) 16(2):80-6. doi: 10.1002/osi2.1018

167. Miquel-Clopés A, Bentley EG, Stewart JP, Carding SR, Miquel-Clopés A, Bentley EG, et al. Mucosal Vaccines and Technology. Clin Exp Immunol (2019) 196(2):cei.13285. doi: 10.1111/cei.13285

168. Jacob S, Nair AB, Boddu SHS, Gorain B, Sreeharsha N, Shah J. An Updated Overview of the Emerging Role of Patch and Film-Based Buccal Delivery Systems. Pharm (2021) 13(8):1206. doi: 10.3390/pharmaceutics13081206

169. Socransky SS, Haffajee AD, Cugini MA, Smith C, Kent RL. Microbial Complexes in Subgingival Plaque. J Clin Periodontol (1998) 25(2):134-44. doi: 10.1111/j.1600-051X.1998.tb02419.x

170. Darveau RP, Hajishengallis G, Curtis MA. Porphyromonas Gingivalis as a Potential Community Activist for Disease. J Dental Res (2012) 91(9):816-20. doi: $10.1177 / 0022034512453589$

171. Lenzo JC, O’Brien-Simpson NM, Orth RK, Mitchell HL, Dashper SG, Reynolds EC. Porphyromonas Gulae Has Virulence and Immunological Characteristics Similar to Those of the Human Periodontal Pathogen Porphyromonas Gingivalis. Infect Immun (2016) 84(9):2575-85. doi: 10.1128/IAI.01500-15

172. Han YW. Fusobacterium Nucleatum: A Commensal-Turned Pathogen. Curr Opin Microbiol (2015) 23:141-7. doi: 10.1016/j.mib.2014.11.013

173. Fine DH, Patil AG, Velusamy SK. Aggregatibacter Actinomycetemcomitans (Aa) Under the Radar: Myths and Misunderstandings of Aa and Its Role in Aggressive Periodontitis. Front Immunol (2019) 0(MAR):728. doi: 10.3389/ fimmu.2019.00728

174. Ghosh SK, Feng Z, Fujioka H, Lux R, McCormick TS, Weinberg A. Conceptual Perspectives: Bacterial Antimicrobial Peptide Induction as a Novel Strategy for Symbiosis With the Human Host. Front Microbiol (2018) 0(FEB):302. doi: 10.3389/fmicb.2018.00302

175. Haubek D, Ennibi O-K, Poulsen K, Væth M, Poulsen S, Kilian M. Risk of Aggressive Periodontitis in Adolescent Carriers of the JP2 Clone of Aggregatibacter (Actinobacillus) Actinomycetemcomitans in Morocco: A Prospective Longitudinal Cohort Study. Lancet (2008) 371(9608):237-42. doi: 10.1016/S0140-6736(08)60135-X

176. Moxon R, Reche PA, Rappuoli R. Editorial: Reverse Vaccinology. Front Immunol (2019) 0:2776. doi: 10.3389/fimmu.2019.02776
177. Liu MA. A Comparison of Plasmid DNA and mRNA as Vaccine Technologies. Vaccines (2019) 7:MDPI AG. doi: 10.3390/vaccines7020037

178. Hou X, Zaks T, Langer R, Dong Y. Lipid Nanoparticles for mRNA Delivery. Nat Rev Mater (2021), 1-17. doi: 10.1038/s41578-021-00358-0

179. Turner JS, O’Halloran JA, Kalaidina E, Kim W, Schmitz AJ, Zhou JQ, et al. SARS-CoV-2 mRNA Vaccines Induce Persistent Human Germinal Centre Responses. Nat (2021) 596(7870):109-13. doi: 10.1038/s41586021-03738-2

180. Li M, Wang Y, Sun Y, Cui H, Zhu SJ, Qiu H-J. Mucosal Vaccines: Strategies and Challenges. Immunol Lett (2020) 217:116-25. doi: 10.1016/ j.imlet.2019.10.013

181. Coffey JW, Das Gaiha G, Traverso G. Oral Biologic Delivery: Advances Toward Oral Subunit, DNA, and mRNA Vaccines and the Potential for Mass Vaccination During Pandemics. Annu Rev Pharmacol Toxicol (2021) 61 (1):517-40. doi: 10.1146/annurev-pharmtox-030320-092348

182. O’Brien-Simpson NM, Holden JA, Lenzo JC, Tan Y, Brammar GC, Walsh KA, et al. A Therapeutic Porphyromonas Gingivalis Gingipain Vaccine Induces Neutralising IgG1 Antibodies That Protect Against Experimental Periodontitis. NPJ Vaccines (2016) 1(1):16022. doi: 10.1038/ npjvaccines.2016.22

183. Yokoyama K, Sugano N, Shimada T, Shofiqur RAKM, Ibrahim E-SM, Isoda R, et al. Effects of Egg Yolk Antibody Against Porphyromonas Gingivalis Gingipains in Periodontitis Patients. J Oral Sci (2007) 49(3):201-6. doi: 10.2334/josnusd.49.201

184. Arastu-Kapur S, Nguyen M, Raha D, Ermini F, Haditsch U, Araujo J, et al. Treatment of Porphyromonas Gulae Infection and Downstream Pathology in the Aged Dog by Lysine-Gingipain Inhibitor COR388. Pharmacol Res Perspect (2020) 8(1):e00562. doi: 10.1002/prp2.562

185. Zhao L, Zhou Y, Xu Y, Sun Y, Li L, Chen W. Effect of non-Surgical Periodontal Therapy on the Levels of Th17/Th1/Th2 Cytokines and Their Transcription Factors in Chinese Chronic Periodontitis Patients. J Clin Periodontol (2011) 38(6):509-16. doi: 10.1111/j.1600-051X.2011.01712.x

186. Dutzan N, Kajikawa T, Abusleme L, Greenwell-Wild T, Zuazo CE, Ikeuchi T, et al. A Dysbiotic Microbiome Triggers T H 17 Cells to Mediate Oral Mucosal Immunopathology in Mice and Humans. Sci Transl Med (2018) 10 (463):eaat0797. doi: 10.1126/scitranslmed.aat0797

187. Gaffen SL, Hajishengallis G. A New Inflammatory Cytokine on the Block: Re-Thinking Periodontal Disease and the Th1/Th2 Paradigm in the Context of Th17 Cells and IL-17. J Dent Res (2008) 87(9):817-28. doi: 10.1177/ 154405910808700908

188. Chang E, Kobayashi R, Fujihashi K, Komiya M, Kurita-Ochiai T. Impaired Salivary SIgA Antibodies Elicit Oral Dysbiosis and Subsequent Induction of Alveolar Bone Loss. Inflammation Res (2020) 70(1):151-8. doi: 10.1007/ s00011-020-01418-x

189. Corthesy B. Multi-Faceted Functions of Secretory IgA at Mucosal Surfaces. Front Immunol (2013) 0(JUL):185. doi: 10.3389/fimmu.2013.00185

Conflict of Interest: The authors declare that the research was conducted in the absence of any commercial or financial relationships that could be construed as a potential conflict of interest.

Publisher's Note: All claims expressed in this article are solely those of the authors and do not necessarily represent those of their affiliated organizations, or those of the publisher, the editors and the reviewers. Any product that may be evaluated in this article, or claim that may be made by its manufacturer, is not guaranteed or endorsed by the publisher.

Copyright (C) 2021 Vaernewyck, Arzi, Sanders, Cox and Devriendt. This is an openaccess article distributed under the terms of the Creative Commons Attribution License (CC BY). The use, distribution or reproduction in other forums is permitted, provided the original author(s) and the copyright owner(s) are credited and that the original publication in this journal is cited, in accordance with accepted academic practice. No use, distribution or reproduction is permitted which does not comply with these terms. 